\title{
Dissilussionment in Postcolonial Urban Literature: An Analysis of Ben Mtobwa's Give me Money and Dar es-Salaam by Night
}

Sam Odhiambo Owino*

Faculty of Arts and Social Sciences Department of Postgraduate Studies

DOI: $10.36347 /$ sjahss.2020.v08i03.001

| Received: 06.03.2020 | Accepted: 13.03.2020 | Published: 18.03.2020

*Corresponding author: Sam Odhiambo Owino

Abstract

This study carried out an analysis of Postcolonial Urban Fiction and its depiction of the theme of disillusionment. Urban Fiction from Africa, especially literature from the East African country, Tanzania, has relatively been less explored by literary researchers. One major thematic concern of postcolonial African writers, on which this study was centered, is disillusionment of the urban underclass. Two of Ben Mtobwa's urban novels Give me Money and Dar esSalaam by Night were used to investigate why disillusionment is a pre-dominant thematic preoccupation of postcolonial urban fiction; the interplay between post-colonial disillusionment and socio-economic as well as political factors surrounding the lives of urbanites; and ways in which disillusionment shapes the urban fiction of the author. The study's central intent was to assess how far the theme of disillusionment pervades post-colonial urban fiction and contributes further in shaping urban life in post-colonial Tanzania as reflected in the texts under study. The study draws upon the argument that post-colonial experiences, as portrayed in the texts, for the most part, result in disillusionment-which in turn becomes highly responsible for the attitudes, consciousness and actions of the urban majority. The choice of the texts was guided by the fact that they quite complement each other in addressing the issue under study. Two literary theories- the Sociological Theory of Literature and the Post-colonial Literary Theory were used in the study. The study employed the qualitative approach which involved a textual analysis of the two novels as well as library research. Data collection mainly involved library research and analyses of both primary and secondary sources. These included the two texts-Give me Money and Dar es-Salaam by Night as well as other primary sources and secondary sources including literary texts, dissertations, theses, projects, journals and books, both print and online. The data collected were presented in the form of descriptions, analyses and logical argument. The findings of the study, among other things; provide invaluable insights into the social concerns and dynamics of post-colonial urban life in Tanzania; highlight various facets of postcolonial disillusionment that are presented in the two texts of Ben Mtobwa; and serve as a reliable source of information that will expand the existing body of knowledge on East African popular literature.

Keywords: Postcolonial Urban Fiction, disillusionment, dynamics.

Copyright @ 2020: This is an open-access article distributed under the terms of the Creative Commons Attribution license which permits unrestricted use, distribution, and reproduction in any medium for non-commercial use (NonCommercial, or CC-BY-NC) provided the original author and source are credited.

\section{INTRODUCTION}

This chapter introduces the study on 'Disillusionment in Postcolonial Urban Literature: An analysis of Ben Mtobwa's Give me Money and Dar esSalaam by Night.' The chapter comprises the Background of the Study, Statement of the Problem, Significance of the Study, Research Objectives, Research Questions, Scope and Delimitations, Limitations, Definition of Key Terms, Theoretical Framework, Methodology, and Structure of the Thesis.

\section{Background of the Study}

Urban Literature in Africa addresses a wide spectrum of issues surrounding urban life in modern postcolonial African states. J. Roger Kurtz notes that there are historical connections between the city and the novel, with the $19^{\text {th }}$ century realist novel, for instance, being largely a product of urbanization in Britain (1415). In the same vein, the researcher argues that African Urban Fiction, for the most part, emanated from the experiences of European colonization of the continent and its aftermath. African writers in the postcolonial era have produced numerous literary works that basically reflect the developments and experiences of post colonialism. A major consequence of colonialism and post-colonialism on which African Urban fiction largely centers is the upsurge of African towns and cities, its attendant socio-political challenges, and the impact, 
especially on the urban underclass. The postcolonial experiences of the various African regions subjected to different European colonial systems have had both similarities and variations. African writers from the various regions have reflected post colonialism from different perspectives depending on their regions' specific unique experiences. There is, therefore, a vast collection of African urban fiction covering an array of post-colonial issues which are yet to be subjected to indepth research study. It is against this backdrop that this study undertook an investigation into African urban fiction and its interplay with urban life. Kurtz posits that in examining the city-novel relationship, not much study has been done that focuses on the post-colonial African setting (15). In Africa, the major historical events, particularly European colonization and its aftermath have had a great bearing on the content and form of literature. African Literature, on the whole, has also been greatly influenced and modeled on the historical periods of pre-colonialism, colonialism, and post-colonialism. These eras were characterized by the pre-colonial African culture, the cultural contact between this culture and the European colonizers' in the colonial period, and the ensuing cultural experiences of post-colonialism respectively. Due to the heterogeneous nature of the indigenous African society and the fact of there being several European colonizers, the field of post-colonial urban literature remains too vast to be exhausted by research. The post-colonial developments and experiences of West Africa, Eastern Africa, and Southern Africa, for instance, have specific unique features which can only be studied individually. Each of the African regions is not homogeneous either. Tanzania, for instance, differs in many ways from Kenya, Uganda, or Rwanda and Burundi in terms of its indigenous socio-cultural systems and post-colonial experiences.

This study, cognizant of the multi-faceted nature of African post-colonial literature, settled on one pre-dominant thematic concern- Disillusionment in Urban Fiction- with a specific focus on Ben Mtobwa's Give me Money and Dar es-salaam by Night both of which clearly reflect the state of affairs in urban Tanzania, especially from the 1970s. The theme of disillusionment cuts across most of African Urban Fiction, a fact that greatly informed the researcher's decision to select it for this study. African Literature in the contemporary era is used largely to depict postcolonial disillusionment among African nations [1]. Indeed, the citizens across all African states continue to wallow in frustration, disappointment and disillusionment, a situation which in turn, further shapes African societies. The late Ben Mtobwa was an internationally acclaimed Tanzanian writer whose realist works of fiction quite vividly highlighted the social ills in the post-colonial urban society in the country. Give me Money incisively reconstructs the Tanzanian society at the height of economic sabotage and massive corruption by a clique of socio-economic and political elite in the 1970s and 1980s. Dar esSalaam by Night, on the other hand, exposes the nature and magnitude of moral decadence in urban Tanzania- a situation which, has persisted in postcolonial Africa, and which this study argues, is strongly connected with disillusionment.

The choice of the author was guided by the fact that, in most of his literary career, Mtobwa had undoubtedly found his niche as a realist writer who clearly and successfully highlighted the socio-political ills in the Republic of Tanzania, particularly in his lifetime. Michael D. Gromov notes that Mtobwa was among Tanzania's most prolific and prominent novelists with African urban modernity running as a major theme across his fictional opus (3-4). Most of Mtobwa's texts reflect the salient concerns of the common man in Urban Tanzania. Secondly, research on the urban fiction of East Africa, especially Tanzania is relatively farther from adequate and the need for literary research into Tanzanian Urban Fiction could, therefore, not be overemphasized. There was a particular curiosity on the part of the researcher to investigate any unique features of Tanzanian post-colonialism and ways in which these are reflected in the two widely acclaimed urban novels by Ben Mtobwa. Give me Money and Dar es-Salaam by Night, quite vividly capture salient social issues that are, also, to a great extent, similar to those of the entire post-colonial Africa to date. This quite resonates with the assertion of Kurtz that urban fiction is, particularly, mostly informed by immediate socioeconomic, political and cultural dynamics in the urban society (15-17). Indeed African Urban Fiction essentially reflects the social challenges faced by the ordinary citizens in their quest to survive in the harsh urban life marred by corruption, oppression and exploitation. The two texts, both written in the late twentieth century, quite complement each other and thus prominently depict disillusionment among the urban underclass. Give me Money presents an almostone-to-one reconstruction of a situation of "things falling apart" in the Tanzanian society as a result of economic sabotage, hoarding, black marketeering and other forms of corruption perpetrated by a clique of socio-economic and political opportunists in the 1970s and 1980s. Dar es-Salaam by Night, on the other hand, highlights the extent of sexual immorality and other forms of decadence in Dar es-salaam and other Tanzanian urban areas, especially by night. This situation remains clearly replicated in the rest of postcolonial Africa, and to a great extent, is connected with disillusionment of the urban citizenry, especially the underclass.

The study elucidated the interplay between post-colonial disillusionment and the actions and consciousness of the urban majority, as reflected in the texts. This study argues that disillusionment is not only a result of postcolonial experience, but also a determinant of urban life and urban fiction at large. The 
citizens get increasingly disillusioned. This situation in turn affects their consciousness and actions in different ways. Some resign to a life of hopelessness and despondency while others seek recourse in various ways, including crime, prostitution and other forms of moral decadence as well as indulgence in corruption. The actions and consciousness of the disillusioned citizens, especially those in urban areas continually shape urban life and urban fiction at large.

Understanding the concept of 'Post-colonial Urban Literature' requires a prior understanding of the meaning of Urban Literature. This study adopted a twofold perspective on urban literature. Paul Daniel McKeown notes that Urban Fiction is not just defined by the presence of the urban setting, but also, by the experiences, attitudes and state of mind of the characters in the texts (1-4). The characters in urban fiction, especially the underclass, grapple with the numerous challenges of urban life, challenges which, as mentioned above, further affect the way they behave and the options they resort to in a bid to fit in urban life. Postcolonial urban literature, in the context of this study, therefore, refers to fiction that addresses the postindependence realities and challenges of urban life in countries that were once under European colonial rule. The referent country in this case is Tanzania.

Disillusionment on the other hand, refers to a state of frustration and disappointment resulting from failure to meet certain expectations in life. This is typically manifested in postcolonial African countries especially among the urban underclass. The urban majority in many post-independence African nations are broken-hearted and disenchanted by the elite who on assuming political power have perpetuated a governance culture marked by corruption and brazen betrayal of their fellow countrymen [2]. This as well as many globalization experiences have continued to shape African urban life in various ways. Increased movement or migration of people facilitated by greatly improved transport infrastructure; easy flow and dissemination of information, ideas and cultural values aided by information technology; increased economic interdependence among nations manifested in free movement of goods and services as well as political interdependence and influence by powerful Western nations are some of the globalization-related factors that also continue to shape the post-colonial African urban society [3].

Philip Etyang observes that the urban poor suffer lack of employment and income, squalid living conditions, limited basic amenities as well as education opportunities among other forms of deprivation (2). This contradiction and negation of the wishes and expectations of the urbanites, most of whom have moved to town from rural areas in search of a better life, results in disappointment and frustration. Kill me Quick [4] by Major Mwangi reveals neocolonialism in
Africa, where "...corruption and rampant scarcity of personal integrity have replaced the hitherto peaceful (pre-colonial) existence" [2]. There are unwarranted arrests and execution of individuals. Indeed, the novel depicts a situation of fear, hatred, humiliation, and repression.

Ben Mtobwa's Give me Money [5] reflects the sorry socio-economic and political state of affairs in Tanzania barely a decade after the ratification of the Arusha Declaration [6], a seemingly well-intentioned framework for building a self-reliant socialist nation. Dar es-Salaam by Night [7], on the other hand, portrays a situation of hopelessness in the city of Dar es-salaam and other major towns of the country. The two texts are translations of the author's Swahili novels, Pesa Zako Zinanuka and Dar es-Salaam Usiku. The study took into consideration the high possibility of a literary work losing part of its meaning and features as a result of translation. The researcher further took cognizance of the debate by literary scholars on 'Language and African Literature'. To this extent, the study struck a balance between the two opposing views by recognizing the possible existence of deficiencies in a literary work done in a foreign language, while at the same time appreciating the inevitable reality of the use of English in African Literature. The study, therefore, incorporated the original Swahili versions of the texts so as to exhaustively capture the issues under study.

The researcher felt the need to delve into Tanzanian urban fiction, which, as already mentioned, is relatively less investigated. The study further sought to investigate any unique features of Tanzania's postcolonial experiences and the literary presentation of the same. The texts both explicitly and implicitly reflect the frustrations, disappointments and subsequent reactions of urban citizens in postcolonial Tanzania. It is these concerns that this study set out to investigate. The researcher sought to reflect the interplay between disillusionment and post-colonial urban fiction with a view to further highlighting the role and significance of disillusionment in the shaping of postcolonial urban fiction and by extension, urban life.

\section{Significance of the Study}

This study set out to address the existing shortfall in research on the interplay between African urban fiction and urban life in African states. The study specifically focused on Tanzania, shedding light on the socio-economic and political state of affairs in the country from the perspective of two of Ben Mtobwa's urban novels. The study elucidated the social causes of disillusionment among the urban underclass and the impact of disillusionment on the social fabric of the post-colonial urban society in Tanzania and Africa at large. The findings of the study are expected to expand the existing repertoire of knowledge on the significance of urban literature in the society. The insights provided by this study will give some direction to both readers 
and writers of popular fiction on the appreciation of Ben Mtobwa's texts-Give me Money and Dar esSalaam by Night, his other texts as well as his authorial ideology. Readers of Literature and literary scholars will further be better placed to appreciate urban fiction and its aesthetics in general. All this will further go a long way in maximizing readership and enhancing the understanding and appreciation of literature on the whole.

\section{Operational Definition of Key Terms -Urban Fiction/ Urban Literature}

Urban Literature in the context of this study refers to popular literature produced in an urban or city setting in which characters from different socioeconomic backgrounds are variously preoccupied with finding means to fit in urban or city life (McKeown1-4).

\section{Postcolonial literature}

This refers to literature set in the postcolonial period in which the writers address the issues of European colonialism and its effects on the social, economic, political and psychological lives of citizens of the former European colonies. This study focused on post-colonial literature from Africa specifically The Republic of Tanzania.

\section{Disillusionment}

This refers to the frustrations and disappointments that are expressed by characters in postcolonial urban fiction who feel betrayed, exploited and oppressed by those in senior positions. This is a reflection of the reality of postcolonial nations in which those who assumed power from European colonizers later turned against their fellow countrymen and have continued to exploit and oppress them instead [2].

\section{Culture}

Culture in the context of this study refers to a particular people's way of life including their language, dressing, food, family life, consciousness, and religious belief systems among others [25].

\section{Popular culture}

This refers to a culture well-liked by many, considered inferior by the elite, yet made by the people for themselves as a kind of reaction to the dominant, elitist culture. This is manifested in such practices as in television programs like soap operas, fashion clothes, video games, slang language use, pop music, comics and pop literature [25].

\section{DISCUSSION}

Factors contributing to disillusionment in ben mtobwa's give me money and dar-es-salaam by night

\section{INTRODUCTION}

This chapter focuses on the first objective of this study- An investigation of socio-economic, political and psychological factors that contribute to disillusionment in the texts-Give me Money [5] and Dar es-Salaam by Night [7]. The study argues that the social realities in the real world of post-colonial urban Tanzania explicitly find expression in the two texts in question. Disillusionment as depicted in the texts under this study is basically tied to real- life socio-political and psychological factors surrounding post-colonial Africa.

Kehinde in an analysis of Major Mwangi's Kill me Quick [4] notes that African Literature is employed as a weapon for depicting disillusionment in African nations (3-7). Post-colonialism in Africa is entwined with European colonization of Africa, and therefore, this analysis begins with brief highlights on the process of European colonization of Africa. Hrituleac notes that the most important phase in the long history of colonization of Africa was the European scramble for Africa in the late $19^{\text {th }}$ and early $20^{\text {th }}$ century (3-9). The colonizer sought to dismiss traditional African ways of life and instead impose theirs. There was then a cultural clash which pitted the indigenous African culture against the imposed foreign culture of the West.

\section{Social effects of Colonialism}

Colonialism resulted in a hybrid culture which, exacerbated by modernism, has been the hallmark of post-independence African nations. Mizutani emphasizes Bhabba's [29] observation that hybridity emerged from the interweaving of elements of the colonized and the colonizer (2-4). The concept of hybridity describes the construction of culture and identity against the backdrop of colonial antagonism and inequity. In this regard, the identity of the colonized Africa, or post-colonial African states for that matter, can only be defined within the context of an in-between, familiar yet new culture. Colonialism, therefore, resulted in a unique 'mix-up' of Western and African socio-political, economic and cultural elements which have greatly informed the experiences of post colonialism in Africa.

Most African texts written in the late 1950s and the early 1960s like Chinua Achebe's Things Fall Apart [9], Ngugi wa Thiongo's The River Between [8], Wole Soyinka's The Interpreters [10] predominantly dwelt on the experiences and complexities of European contact with Africa.

Arguably, there are pro's and con's to European colonization of Africa. It is indeed unfair and illogical to ascribe all failures and misfortunes bedeviling post-colonial African nations to European colonization of the continent. European colonization was so extensive in terms of geographical scope, the colonizers' heterogeneous practices, and impact, thus making it difficult to come up with blanket generalities on the subject (Loomba 2-3). Perspectives, emphases and inclinations regarding this subject, therefore, depend on other factors like disciplinary affiliation, 
geographical and institutional location, and the area of expertise. On the technological and educational fronts, for instance, it can be argued that the African continent, has received monumental advantage from European colonialism and contact with the West.

Technological advancement and the development of formal education in Africa have shaped the entire African continent in a myriad ways. In absolute terms, therefore, this study takes an ambivalent position as to the role and impact of European colonization of Africa.

In delving into disillusionment and postcolonial urban fiction, however, this study draws a connection between the socio-economic and political malpractices in post-colonial Africa on the one hand, and European incursion and colonization of the continent on the other. The researcher of this study observes that the social malpractices associated with post-colonial Africa largely emanated from European contact with Africa and were further exacerbated by the post-independence African ruling elite, who found these by all means expedient to them. The experiences of post-colonialism are, therefore, largely ramifications of European colonial contact with Africa.

On the economic front, for instance, the colonizer gave land, labor and many other hitherto social activities a monetary dimension [11]. Hrituleac observes that socio-politically, the indigenous African systems were disorganized, disoriented and effectively collapsed by the colonizer. In Tanzania, for example, the chiefdoms were virtually collapsed by the German and British colonial systems. Among the negative socio-economic and political repercussions of European colonization in Africa, which post-colonial African States continue to grapple with are extreme capitalism and consumerism, alienation, oppression, exploitation and massive corruption. The socio-political and cultural elites in African states have perpetuated corruption and exploitation of the ordinary citizens. This vicious circle of Western-related malpractices implanted in Africa and readily adopted by most highly placed African state officials has had a great psychological bearing on the majority African underclass, especially those in urban settings. The Republic of Tanzania has been largely more peaceful and socially intact in comparison with its neighboring states like Burundi, Rwanda, Uganda or Congo. However, over time, the citizens especially the urban masses in post-colonial Tanzania just like in most of Africa have not been spared the ever-growing ordeal of disillusionment and its attendant complexities.

Give me Money [5] centres on Kandili Maulana, the main character, who is lured into a syndicate of extremely wealthy economic saboteurs led by Idrisa Kalulu, the Managing Director of the only African factory that manufactures the drug, Oxton. Mtobwa [30] uses this factory to exemplify the plight of the ordinary citizens and the workers who continued to suffer exploitation under a few selfish, corrupt leaders and government officials. The factory is in Arusha, Tanzania. There are only two such factories on the entire globe and, therefore, the drug, which cured the then highly prevalent children's disease, Palala, was in extremely high demand. Kandili, Kalulu and Bon Kolo work in cahoots to engage in the trafficking and hoarding of the essential drug. The drug barons get extremely wealthy and influential, managing to compromise the police, the judiciary, the media as well as the medical personnel. The syndicate engages in the trafficking and hoarding of more essential commodities like sugar, salt, medicines, and clothes.

As corruption, capitalism and consumerism deepens in the society, majority of the citizenry live a life of misery marked by unwarranted deaths of children, extreme poverty, starvation, dehumanization, crime and prostitution. Honest Prosper Ngowi [12] notes that the Tanzanian society was during the 1970 s and 1980s facing a serious socio-economic crisis. The gap between the rich and the poor was getting increasingly wider. In the text, economic saboteurs led by Kalulu, Kandili and Bon continue to amass wealth even as the country's economy gradually collapses.

The situation for the ordinary citizen is compounded by the fact that the political leadership is comprised of individuals who, prior to joining politics, have exhibited betrayal, greed, selfishness towards the citizenry. Idrisa Kalulu, the Managing Director of the Oxton factory later becomes a Member of Parliament and Minister for Human Rights. At the height of economic crisis in the country, the already-besieged government gallantly launches a belated crackdown on economic saboteurs.

The feeling of disillusionment is palpable among majority of characters in the text. Mtobwa writes of Kandili Maulana when he finally landed a job in Arusha:

He began his work with all the enthusiasm which had been bottled up inside him. But it did not take him long to find that his hopes were like sweet dreams which brought no real rewards. His salary was not enough...The cost of living was rising faster and the value of money continued to drop....Prices rose faster than he could cope with and this was followed by the scarcity of essential commodities (25-26).

This part expresses Kandili's disappointment shortly after he landed his first job. Despite his initial enthusiasm and valor, as a newly-employed youngster, he was soon to realize that urban life was getting increasingly expensive even as his salary remained too meager to sustain him. Kandili (whose expensive secondary school demands is said to have 'sucked his 
mother dry like a twig') soon loses his zeal as he discovers that his meager salary can hardly fend for his needs as well as those of his school-going siblings at home and his frail, aging mother. To compound matters, the cost of living is sky-rocketing even as the value of money continues to nosedive.

Dar es-Salaam by Night [13] depicts the city of Dar es-salaam, as extremely amorous and decadent, with many night-clubs, bars and brothels being full of prostitutes either searching for, or in the company of male clients. The streets which are mostly lit by night are dotted with either men and women moving in pairs to various destinations, or skimpily dressed women loitering about in search of men. The patrons of the social places comprise the prostitutes, black marketeers, economic saboteurs, confidence tricksters and other criminals, some of whom, out of frustration in life, either seek for escapism, or try their luck at night crime.

The main character, Rukia has been compelled by circumstances to indulge in prostitution at a very young age. Her prostitute mother abandons her and elopes with a white man to the city of Nairobi, Kenya. Rukia, an extremely beautiful young girl soon becomes an accomplished whore, spending most of her time with older men in night clubs, bars, brothels and hotel lodgings. She soon gets infatuated with Peterson, an extremely wealthy middle-aged business man who significantly changes her social status. He buys her a house and treats her to numerous flamboyant romantic escapades.

The character traits and actions of Rukia, Peterson, Hasara, and Hasira all smack of intense disappointment and frustration. Hasira's name is actually a Swahili word for "anger", while "Hasara" means "loss". Hasira in one of his many conversations with Hasara laments:

"Why do you call me Hasara? Have you ever heard anybody called by that name? Had you been someone, the son of a man, you would have liked those children. You'd have eaten better, slept better and put on better clothes. You'd be going to school and leading a decent life. You wouldn't be sleeping in dirty corners and scavenging like a dog." (10)

This is a typical scenario in most post-colonial African states, where the post-independence dreams of the citizens continually get brazenly shattered by the minority group of political and economic elite. The betrayal of the ordinary citizens by their fellow Africans in the top echelons of socio-economic power seems to be consigning the citizens to a harsh life of misery and poverty. Governance systems get increasingly corrupt. This results in disappointment and despondency among the ordinary people who in turn react variously to this state of affairs. The elite in the society relentlessly continue to amass wealth at the expense of the common man. In Give me money, for instance, Kandili's disillusionment as a result of the many hardships he encounters in his earlier life changes his perspective on life and he finds himself lured into corruption, which catapults him to a life of immense wealth even as his victims wallow in wanton poverty and disease. There's therefore a notable interplay between socio-political and economic factors surrounding post-colonialism on the one hand and disillusionment on the other. In this case, these factors cause disillusionment to the majority citizens who in turn react in different ways thus further shaping their societies politically, socially, and economically.

\section{Factors contributing to Disillusionment in Give me Money [5].}

Literature reflects the life of a people. Kehinde observes that "a study of any writer may tend to be defective if an attempt is not made to locate his/her major thematic concerns within the totality of the history of the writer's society" (224). Molvaer further notes that a society is the co-author of literary works since the works are basically its reflection (qtd. in Makokha 3-9). In Give me Money, Ben Mtobwa reflects the realities of post-colonialism in Tanzania during his lifetime (1958-2008). In order to clearly conceptualize post-colonial disillusionment in the texts under study, this analysis includes brief highlights on the Tanzanian society from the pre-colonial era, through the colonial period to the present post-colonial era. Prior to colonialism, socio-political organization in Tanzania varied widely, ranging from the simplest (communities organized at the clan or group level) to the highly structured and more centralized hierarchical chiefdoms like the Chagga, Hehe, Ngoni, Nyamwezi, Gweno or Sangu (Lindemann and Putzel 12-15). By and large, this multi-ethnic society was not tribal-based and remained socially intact.

Under European colonial rule in Tanzania, the political, economic and military structures of precolonial societies were severely weakened as the new socio-political systems openly discriminated against Africans in favor of Europeans and Asians. Colonial rule deliberately collapsed indigenous economies in Tanganyika. A settler and plantation agriculture was introduced whereby labor on the farms was used to generate revenue. Rural peasants were also enlisted through their products in the national economy. Imposition of taxation meant people had no option but to seek employment or engage in sale of their products. This effectively coerced people into joining the money economy.

Stephan and Putzel observe that colonial rule in Tanzania laid the foundation for a certain degree of uneven development. The site for development of infrastructure, for instance, was only determined by the presence of cash crops in the areas (13-15). This 
disparity was to eventually spill over to the citizenry, with the dichotomy between the minority elite and the ordinary citizens getting increasingly wider. Mtobwa's Give me Money right from the beginning aptly reflects the magnitude of economic disparity among the citizens of the Republic of Tanzania. In its first instance of juxtaposition the text pits Kandili Maulana against Bon Kolo. The Swahili version-Pesa Zako Zinanuka [14] describes Bon Kolo thus:

...kijana mashuhuri mwenye sifa nyingi zilizomfanya mashuhuri kama chumvi katika jiji la

Arusha na vitongoji vyake. Moja ya sifa hizo zilikuwa matumizi....Jina lake lilikuwa maarufu

katika kila baa kubwa, sura yake ilikuwa mashuhuri katika kila hoteli muhimu na sahihi yake

ilikuwa maalum katika vitabu vya vyumba vya wageni....aliandamana na msichana au wasichana wazuri wazuri ambao ndio walioijua na kuitoa siri halisi ya utumiaji

Wake...kamwe

hakuihurumia noti yake (6-7).

In the excerpt above, Bon Kolo is described as a notorious spend-thrift, a flamboyant, wealthy, young man whose name was familiar in every bar and hotel and his signature had been scribbled in almost every guest register in Arusha's lodging houses. The Swahili version above likens Bon Kolo's fame to salt, an implication of the value, fame and popularity of salt as an essential commodity in the society in question. Bon Kolo's affluent life is further described thus:

...he had put up an enormous mansion in an amazingly short time... The mansion could easily have housed two families. It was painted in different colors and surrounded by beautiful flowering plants. Always infront of the mansion two expensive saloon cars, his favorite being a Benz and the other a Peugeot 504 were parked waiting for him (7).

Kandili on the other hand, hails from a poor background. He was the first born child in a family of nine children with a poor widow mother as the head. His father had died of cholera when Kandili was only ten years old (24-25). As an adult he could not be mentioned in the same breath as Kolo in terms of socioeconomic status. When Bon suddenly snatches Maua from Kandili, the by-standers laugh at Kandili telling him he "is no match for the likes of' Bon. "You have no car, no money," they tell him.

The affluent in the society are unrelenting in exploiting and oppressing the majority (underclasss) who are already impoverished. Kehinde (226) observes that the ruling elite openly display indifference to the plight of the ordinary citizens. There is blatant contempt for the lowly in society. Bon, a fellow African exemplifies this when he lands blows on Kandili's cheeks for no apparent reason. His militia-man and hooligans rough up Kandili at his work place, forcing him to sit on the floor and have his hands and feet tied (12). This is done with the full knowledge of Kandili's boss, the Managing Director, Idrisa Kalulu. Kandili is framed up and arraigned in court where he is sued for assault. The system victimizes and oppresses the ordinary citizens and uses all manner of schemes to get their subjects to serve their whims. The judicial process is also sucked into corruption. Bon later tells Kandili, "....all that happened ...was deliberately planned...the militia-man, the police and the magistrate were all in our pay" (15). Mtobwa writes, "Nobody listened to his defence and he was thrown into prison where he suffered more than he had expected" (13-14). The author furtherwrites:

And on top of what he had suffered in prison, he was worried by the realization that he had now lost both his job and self-respect....Jobs were hard to come by especially for a young man like him who did not have relatives or god-fathers in high places (14).

The predicament of immigrants into the urban areas is further complicated by the fact that majority of them would rather remain suffering in the cities than go back to their rural villages. Kandili at some point thought of going back home, but then "pushed back the thought out of his mind." How could he bear to see the face of his old, widowed mother who had eight other children who all depended on him? (14). Opportunities for decent living for the ordinary urban citizens are greatly limited. This causes them anger, frustration, low self-esteem, and in some cases, depression. Kandili had to keep his family upcountry out of this woeful state of affairs and remain in Arusha town. He had to survive despite the ordeal he was undergoing in town. Mtobwa writes, "As far as Kandili was concerned, Bon had already killed him and only his carcass was left staggering about" (8).

Kandili had only been released from prison a few days ago and the previous night he had been evicted from the room he had rented. In both cases Bon had a hand. Kandili feels he would rather kill Bon, be 'hanged and finished with rather than continue to rot in the state Bon had reduced him to..." (8). Kandili's frustrations do not only emanate from the experiences he has been subjected to by Bon. As already outlined, his frustrations and disappointment dates back to his entire earlier life right from childhood.

One central argument of this study is that individuals in the society do not necessarily take frustrations and disappointments lying down. The 
socio-political and economic factors cause the urban underclass disillusionment. In consequence, the citizens react differently, further altering the socio-political fabric of their societies in different ways. George Simmel, for instance, in an essay titled "The Metropolis and Mental Life" [15] notes that the individual in the urban metropolis is faced with a barrage of imagery and stimuli which in turn causes an increase in the individual's awareness and intellectuality- cognitive processes that allow the individual to absorb and deal with intensified stimuli (qtd. in McKeown, 5). Simmel argues that the intensification of nervous stimulation in the city causes the metropolitan individual to "react with his head instead of his heart" (qtd. in McKeown, 45 ). The complexity of life in the modern metropolis allows the urban mentality to develop an "unmerciful matter-of-factness". McKeown seems to imply that the metropolitan is faced with situations that predispose if not tempt him/her to acting out of emotion without reason. This study holds that Simmel's argument, though not plausible in all respects, is applicable to a considerable number of characters in the texts under study. McKeown further argues that an adequate investigation into urban fiction should include an exploration of the individual-city relationship (2-4). The modern urbanite mind is increasingly calculating. The interaction between the individual and the city further shapes urban fiction and urban life in general.

As discussed below, Give me Money, is centred on the way Kandili, the main character, changes and becomes the main agent and mastermind of corruption and economic sabotage in the society in question. The same can be said of Bon Kolo, Idrisa Kalulu and Maua. Characters develop new traits or resign themselves to new lifestyles as a result of the experiences they encounter. McKeown notes that urban fiction on the whole addresses such thematic areas as colonialism, nationalism, ethnicity, art and popular culture, social class, occupation, family, sexuality, gender, religion and substance abuse (12). These issues quite relate to the urban experiences particularly in post-colonial Africa.

Independence from European colonization was not a panacea for Africans as they had wrongly believed. Post-independence Africa was inevitably accompanied by the legacy of colonial indoctrination which included socio-political systems like the franchise, factionalism, and politics of regional, ethnic, and language groups. Although Tanzania was not affected in this regard as much as most former colonies of Europe, the disappointment arising from unmet expectations among civil servants, workers and peasants triggered disunity and unrest in the postcolonial Tanzanian society. So many years into independence, citizens were continuing to languish in poverty, disease and squalid living. These were some of the pre-independence challenges which the citizens had hoped would be solved soon after independence. These citizens had been promised and could not wait to see the much longed- for social services, employment opportunities as well as higher incomes, and a general improvement in their living standards. The realities of post- colonialism soon began to set in.

The first years of Tanzania's independence were, therefore, marred by industrial disputes, the violent overthrow of the government of Zanzibar in 1964, and the mutiny of the armed forces of Tanganyika [12]. By mid 1960s discontent among peasants, workers and emerging nationalists was rising towards its peak. In response, the Arusha Declaration [16] was made, with President Nyerere spelling out his visions of a socialist society, self-reliance, and emphasis agriculture and rural development. The enforcement of these changes too met some opposition from certain quarters especially those who did not want the status quo to be upset.

Tanzania's war with Uganda in the late 1970s presented yet another set of serious challenges [12]. Although Tanzania succeeded in subduing Ugandan forces (in 1979), the war presented a new set of socioeconomic challenges. There was an economic development opportunity cost resulting from the war. The resources (financial, human and time) used in the war could have immensely contributed to economic development in the nation (African Association 13-15). Other effects that drastically impacted on the country's economy due to the war were destruction of infrastructure and properties, lost lives, and civilians' inability to work optimally during the war period. Besides, instability, whether domestic or regional, has been known to have severe negative economic effects on a country particularly due to reduced trade. In addition, the war had resulted in a proliferation of militias in the country. Containing the militias proved a daunting, expensive task and more attendant problems like increased crime emerged. During this time, corruption among the socio-economic elite was rising at an alarming rate. Mtobwa writes of Kamkanda, "Before the war, no young man could have been said to be as happy as Kamkanda" (39). Things seem to have fallen apart in the Republic of Tanzania during and after the war. Kamkanda's home in Mtukula is said to be one of the very first ones to be razed to the ground by artillery fire. Kamkanda had witnessed the torturing and death of his parents and fiancée from his hideout. Kamkanda was heartbroken and wretched (39).

During the short period of the war there people had appeared who wished to exploit the circumstances for their selfish ends. These people compounded the problems which the country faced after the war. Hoarding, black marketeering, smuggling, theft of public property, corruption and other evils became the order of the day (40). 
The masterminds and stewards of economic sabotage were busy perfecting the art of hoarding and overpricing essential commodities with abandon. In the early 1980s, Tanzania was hit by a serious economic crisis as a result of currency over-valuation, low producer prices, parastatal mismanagement, declining terms of trade, the oil crises of 1974 and 1978, the droughts of the mid-1970s, the break-up of the East African Community in 1977, and the war with Uganda between 1977 and 1979. As Ngowi observes, the political and socio-economic tensions like the crackdown on economic saboteurs from 1983 further compounded the situation in Tanzania.

Give me Money [5] is basically set around corruption and inhumane activities of powerful economic elite who brazenly thrived on mismanagement of government institutions and economic sabotage. The text centres on a manufacturing company, TOKO, which deals in manufacturing Oxton. Oxton was a special powder solution invented to combat a new malignant disease (pallala) which was killing children the world over. There were only two factories in the world making the solution: one was in London and the other was in Arusha. Oxton was, therefore, a highly-treasured commodity especially due to its rarity. Idrisa Kalulu is the Managing Director of this company and Kandili is employed as the stores clerk. Idrisa in collusion with Bon, an accomplice, have employed Kandili in a clerical capacity to aid in running the illegal traffic of oxton powder without the knowledge of other employees in the factory. At first Kandili is reluctant and apprehensive but after running out of options he gives in to the duo's wellchoreographed schemes which had at some point seen him imprisoned. Bon tells Kandili, "All you have to do is cook the reports. The false reports will be approved by your boss. The rest will be my responsibility" (23).

The text largely presents Kandili, the main character as a key agent of corruption and economic sabotage-an immense contributor to the disillusionment that afflicted majority of the citizens in the society in question. The deplorable situation for the ordinary citizens does not seem to improve but rather, increasingly deteriorates. This is, to a great extent, due growing cases of betrayal of the citizens by individuals who fall prey to the alluring temptation to join the corruption bandwagon. The top management of the factory including the stores clerk, Kandili use all manner of plots to rob the people of the medicine meant to deliver them from the power of the deadly epidemic. Large contingents of Oxton bottles which were to be distributed to various regions would mysteriously disappear courtesy of a few individuals who were involved in the trafficking of the powder. The workers in the factory worked round the clock but were puzzled that their products were mysteriously disappearing. Bon tells Kandili:
"Now tomorrow we're coming to remove the last contingent in the store. The trucks are ready. They have the Tanzanian registration numbers to give the impression that the medicine is being distributed here while in fact we're smuggling it out of the country. In this way we'll get the foreign currency which is much more profitable". (34).

The factory's union secretary Kanda wa Kamkanda urged his chairman, Kombo Mtolondo to take up the issue with the Managing Director Idrisa. To the disappointment of the workers, their union chair on meeting the Managing Director is persuaded into backing off with a promise of a scholarship in Britain (37-38). Some of the union leaders on whom the frustrated and exploited workers bank their hopes are also becoming a let-down. Workers are left on their own to wallow in complaints and bitterness even as their children continue to die and the fruits of their labor goes to just a few individuals.
"Kamkanda's bitterness was not surprising...he had every reason to sorrow for his country. This sorrow had permeated his whole being from the day he had arrived back in his home village from the war in Uganda and found everything contrary to his expectations"(38-39).

When Kamkanda takes up the issue of the disappearance of Oxton with the Managing Director after their chairman's disappearance, he is slapped with a letter of summary dismissal. For a long time the relevant government agencies and institutions remained compromised and complicit in theses illegal activities. Bon remarks that the patrol cops have already received their back-handers and could not cause any trouble on the way. The police had in fact in one instance warned Kamkanda when he went to report, "If you come here with any more baseless rumors, you'll be sorry"(46). Bon further says that every guard at the factory had received his hush money (43). Kamkanda while in hospital after attack by Bon and his accomplices spills the beans before a news reporter in the hope that the media would expose the matter.

Idrisa Kalulu, the Managing Director of Toko the Oxton manufacturing company is a beneficiary of Western education just like is the socio-political and economic elite of most African republics. He had, in fact, won a scholarship to the United States. On returning home he had been able to amass wealth through cunning ways. This he did in contravention of the Leadership Code in Tanzania which prohibited public servants from using their positions to accumulate wealth. He would register businesses under false names and take care not to be associated publicly with those who ran these businesses. As a result of his massive wealth, he is able to have his way in many of his 
corrupt deals. He succeeds in compromising not only key government officials but also the media and medics. When he learns from the police that Kamkanda is on a mission to expose their deals he uses Maua, his lady accomplice to arrange with the doctor to have Kamkanda killed while in hospital.

Maua succeeds in persuading the doctor into committing the malpractice. She instructs the doctor:

Let him not recover. We want you to help him die. There's a reward for the job. One hundred thousand shillings. I'll give you the down payment of fifty thousand shillings now. When you've finished the little job I'll give you the rest in full. And of course there's my body whenever you need it (57-58).

Corruption is pervasive in the society and is perceived as the only means to financial success, especially by the middle working class. The doctor, on thinking of the many financial problems that always embarrassed him tells Maua, "Don't worry darling...I'll do as you wish." The doctor goes ahead and administers a lethal drug to Kamkanda who then passes on. One day after Kamkanda's planned death in hospital, the newspaper publishes a distorted piece of information purporting that the police had in a fire exchange succeeded in killing two of the gangsters (Kamkanda included) who broke into the godown of the Oxton factory with the intention of stealing the drug. The remarks by majority of citizens who get wind of the fabricated news in the newspaper all allude to serious disappointment. One remarks, "I believed the newspaper was the voice of the oppressed...the voice of justice." Another one wonders, "so what can we do? I see no hope." One voice is heard saying, "Some of those to whom the government entrust responsibilities are those self-centred ones who work for only their bellies. Just think of an old official with a healthy bank balance demanding a bribe of five hundred shillings from a poor youth who is looking for a job". Kandili Maulana, a once lowly-paid stores clerk had by now become a corruption baron. He all of a sudden had a fleet of Lorries, and was building his fifth hotel. He also had a string of bars. His businesses were registered under other people's names.

Kandili also dealt in minerals such as gold, diamond and tanzanite. He had also employed poachers whom he supplied with weapons to secure him elephant tusks, leopard skins and other trophies which he smuggled out of the country (63-64). On top of this, Kandili together with Bon continued to engage in smuggling and hoarding of commodities which the citizens were in dire need of. The commodities which were being hoarded included sugar, soap, salt, flour, clothes, and medicines. Kandili and his accomplices' hoarding deals were often bankrolled by capitalist forces whose aim was to antagonize the people against the government and its policies of socialism and self- reliance. Towards the end of the text, the hitherto relaxed government is seen to begin cracking the whip on economic saboteurs. At first a commission set by the government to investigate in the problems in the Oxton factory is bribed into producing a false report exonerating the top management of the factory.

The people and the workers continued to grumble as days went by. Socialism is said to remain only on the lips of most of the political leadership. Elected union representatives are also compromised through various enticements into betraying their fellows whom they should be representing. This is seen in the case of the union chairman in the Oxton manufacturing factory. The union leader is enticed with a promise of a scholarship abroad. He therefore abandons his noble mission of advocating for the rights of the oppressed workers. The political leadership has perfected the art of eloquence and empty rhetoric. Idrisa Kalulu the man behind the smuggling and hoarding of Oxton drug and other essential commodities in Tanzania joins politics. $\mathrm{He}$ is elected Member of Parliament and appointed Minister of Human Rights. Disappointment, frustration and disillusionment have driven the likes of Dora into a life of prostitution. Her wish was to find a legitimate job....Many potential employers demanded a bribe from her in cash or in the form of her own body.... She ended up landing a low-paying job which she accepted to prevent her from dying of starvation (83).

\section{Factors contributing to Disillusionment in Dar es- Salaam by Night [13]}

Dar es-Salaam by Night was first published in Swahili as 'Dar es-Salaam Usiku' [7]. It is centered on the story of Rukia Komba, Peterson, Hasira, and Hasara among other characters. The setting of the text is Dar es-salaam city. Other towns like Mwanza are also featured. A closer look at the text reveals that it depicts a society in which the urban underclass is a frustrated and disillusioned group. Themes like unemployment, corruption, crime, class difference as well as prostitution, poverty and education have been elaborately addressed in the text.

Gromov [17] observes that Dar es-Salaam by Night bears some features that distinguish it from the ordinary love story. The heroes in this text are presented "as products of their social environment, of the vices of the society they live in" (151). Rukia finds herself in prostitution at a very tender age. At her initial stages of prostitution, Mtobwa writes:

...Her eyes were haggard with sorrow and her dress so nondescript that even potential customers hesitated at first glance....But the girl would not let her age come between her and her determination to make a living....for three days now, her tummy had known no food. (2-3). 
This part right from the onset presents a very sorry state of affairs for young, otherwise innocent lass. Poor parenting, child negligence and poor role models, especially in the residential conditions of the urban underclass, are responsible for the growth of immorality-associated behavior in society. Mtobwa explicitly writes that Rukia had over time learnt from her mother the practice of sexual decadence:

As soon as she had grown old enough to learn, she had observed her mother ... with men who threw her into bed on her back or on her belly...later she discovered that those cries were different ... from the way she did that night when one of her customers physically assaulted her, spraining her ankle and knocking out her tooth (3).

Rukia learns from her mother not only about sexual decadence, but also violence and physical assault against women by men. Rukia's neighborhood is also described in the text, "There was that son of their neighbor, a young boy slightly older than her. Whenever they were alone they would shut themselves up in a room and enact what their mothers did openly" (4). Rukia is a case of a girl-child from a poor and shambolic family background bred in an environment that predisposes her to sexual immorality and negatively shapes her moral character. She only has four years of primary education. Her mother abandons her at a very early age.

This situation of poor parenting and negative, poverty-related environmental influence is replicated in the lives of other characters in the text as well. Hasara did not know the whereabouts of his parents. He grew up as a street boy and has no idea how he began that kind of life. "All he knew was that as soon as he had gained an awareness of his existence, he had found himself among dirty, poor children who lived on picking dumped left-over food from dustbins"(8). Hasara's mother who also happens to be Rukia's mother represents the women who, for lack of alternative means of livelihood once in urban areas, resort to prostitution. The urban underclass is compelled by circumstances to resort to a life of indulgence and moral decadence. In adult hood Hasara is still dependent on luck to earn his daily bread and so are many other children and adults.

He still saw many children living the way he did and many adults roaming the streets begging. He also knew of families which were so poor that their members went without food... Yet he also knew of rich people who juggled money like they do poker-cards and had more than they could spend (13).
While waiting for his friend Hasira in a coffee bar in Dar es-Salaam, Hasara is said to have recognized among the patrons a group of "black marketeers, saboteurs, prostitutes and confidence tricksters. Mtobwa notes that most of these patrons lived a life of crime and "emptiness" deceptively concealed by their clothes (8). Hasara could not see any difference between his childhood street life and his current one. It is not only Hasara who portrays this frustration.

Hasira, for instance, had moved from his rural village in search of a decent life in town. The environment of his rural home is described when he goes upcountry:

The hut belonging to Hasira's parents was surrounded by an uncared-for maize garden. It was dark both on the outside and to the inside. Eventually the door had been thrown open. ...the four things that had been lying still in a corner of the hut looking like logs came to life (when they heard of Hasara's visit).They were actually human beings wearing hides and pieces of calico (45).

Hasira feels not only obliged but also compelled to live in the city and try to fend for himself and if possible, financially assist his siblings and old parents. Peterson, on the other hand, is described as extremely wealthy. His double storey residence is said to reverberate with the sound of music and the hustle of servants. The house was equipped with the latest airconditioning gargets. This is in sharp contrast with the life of majority citizens in the city of Dar es-salaam a good number of whom are living in the city's streets. As already outlined, frustration and disillusionment further causes individuals to resort to various lifestyles. Crime, prostitution and many other forms of moral decadence increase. Dar es-salaam city by night is time for the rich to spend their life on indulgence in a life of decadence. The majority who comprise the urban underclass are also not left behind as they too seek solace in alcoholism, prostitution and all manner of criminal activities. Bars were said to be noisy with drinkers. "Prostitutes hung about the streets and drinking places, crossing paths with nocturnal thieves and gangsters" (20). Crime is on the rise in Dar essalaam. Hasira is enlisting Hasara in a conspiracy to kill Peterson. He promises Hasara sufficient money in pay, to liberate him from his poverty (34).

The text reflects the big magnitude of corruption and other forms of inequalities in Tanzania during this period. Meritocracy had been replaced by nepotism, favoritism and bribery-practices which resulted in mediocrity. Mtobwa in fact, writes that the business tycoon, Peterson too had earlier on realized that his high school education was a waste of time. Peterson says he had realized that what mattered in the 
country was who you knew. Knowing people who mattered and having them know you was more important than the paper qualifications (74). The leadership in many government institutions and agencies was marked by mediocrity and incompetence. Hasira remarks, "You know people who are really free in this country are very few. ...we are all their slaves, sweating day and night and spilling our blood for their benefit and that of their children and even concubines?

" In one instance Hasira laments:

Of what is life to you in this world? They employ every kind of trick to keep us trapped in this mire of poverty to deny us freedom. They mock at our efforts to liberate ourselves from the bonds of poverty and misfortune.... They advance themselves bank loans which they don't pay. They award themselves scholarship opportunities...They make sure they are better medical facilities while we are left to die like beasts...the award themselves licenses for the most rewarding lines of business...we are condemned for slaving for them forever (90-91).

At the end of the novel, Rukia, Hasara, and Peterson are presented as a broken-hearted disillusioned lot, especially after learning that they are actually relatives. Hasara and Rukia have their hopes for marriage totally shattered. Peterson, on the other hand, a relatively older man, is consigned to a feeling of guilt for having kept his real sister as a mistress for so long and having kept his biological father as a servant in his house.

\section{DISCUSSION}

How disillusionment shapes setting, characterization and themes in give me money and dar-es-salaam by night

\section{INTRODUCTION}

This chapter delves into the second objective of this study, the influence of disillusionment on setting, characterization and thematic concerns in Give me Money and Dar es-Salaam by Night. The fictional city and the influences it has over a character and the reader can be likened to a real city and the effects it has upon the society. McKeown notes that the fictional city has physical characteristics which spatially prescribe parameters for sociological and psychological movement (8). There is, therefore, an automatic interplay between the post-colonial fictional city and the formation of characters in a text. As discussed in more detail below, popular or urban fiction is distinctively defined by its setting which in strict sense is largely urban; its characters most of whom are the lowly in society, grappling with the challenges of urban life; and its thematic concerns which consist in socioeconomic hardships and the disparity between the elite minority and the ordinary citizens who constitute the majority. This genre of literature is sensitive to and largely focuses on the dark underside of urban society; it targets the ordinary citizens who also constitute the average readership category.

The phenomenon of disillusionment in Give me Money and Dar es-Salaam by Night has a bearing on the way the primary texts in this study have been structured not only in terms of setting, but also, in characterization and thematic concerns. The two texts are both set in Tanzania's urban centers in the postcolonial era-the towns of Dar es-Salaam, Arusha, Mwanza and others. It is in the urban cities that the experiences of post-colonialism are at peak level. Disillusionment is a pre-dominant experience not only in Tanzania but also in the rest of post-colonial African states. It is the majority African urban underclass that directly bears the brunt of post-colonial challenges.

\section{Disillusionment and Setting in Give me Money and Dar es-Salaam by Night}

This sub-section begins by defining the term 'setting' in literature. Setting comprises the physical environment of a text; the time of the event(s) and action(s) of the text; the social environment of the characters as well as the resultant mood, atmosphere or emotional effect thus produced. The physical aspect of setting addresses such questions as the place, country, town or locale of action; the sensuous qualities of the place; the relationship between the place and characters and themes among others. The time aspect of setting refers to the historical period of the action, duration of the period and the interplay between these and characters as well as thematic concerns. The manners, customs and moral values of the society in question constitute the social environment component of setting.

The text Give me Money is set mainly in urban Tanzania particularly in the city of Arusha in the postcolonial period. During the period (beginning around 1970s) the actual republic of Tanzania was facing serious socio-political and economic challenges [12]. It was a period in which the country was grappling with the challenges of the implementation of the policies of the Arusha Declaration [6]. The fruits of the goodintentioned Ujamaa policies were not materializing. In consequence, the immediate post- independence capitalist and consumerist policies and tendencies were re-emerging in earnest.

The cosmos represented in Give me Money is that of a poignant tale of neo-colonial oppression and exploitation of the ordinary urban citizens. TOKO, the Oxton manufacturing factory is based in Arusha. The factory is headed by extremely wealthy and corrupt individuals who engage in hoarding and trafficking of the drug and other essentials. Their network of corruption involves officials in key government institutions including the police, the judiciary and the 
medical personnel. The sufferers and victims of this state of affairs are the workers and the ordinary urban citizens. There seems to be nobody to address the many grievances of the workers and the urban underclass majority most of whom continue to languish in poverty and suffering. The text paints a picture of suffering, oppression and economic exploitation. It further presents a tone of hopelessness and despondency among the Tanzanian ordinary citizens.

Like in many African states, many citizens have moved to urban areas in the hope of escaping the poverty associated with the countryside. People move to towns in search of employment in the hope that this will enable them to fend for their needs and those of their aging parents and young siblings. Disappointment greets the rural-urban immigrants as they soon learn that jobs in towns are scarce. Many immigrants into the urban areas encounter the reality of joblessness and the accompanying socio-economic hardships.

A significant number of individuals in the urban areas also include children most of whom end up resigned to street life. Joe L. P. Lugalla and Jessie Kazeni Mbwambo note that the problem of street children is acute in the Republic of Tanzania especially in the cities of Dar es-Salaam, Arusha, Morogoro, Moshi, Tanga, Mbeya and Mwanza(329). The continuing increase in population amidst an intensifying and severe economic crisis is to an extent responsible for the proliferation of street life on the urban streets of Tanzania and many African nations. While some of these children have been abandoned by their families, others have for some reasons, of their own volition escaped from their families, migrated to the cities in search of a livelihood and ended up in the urban streets. These children sleep in the streets or on the pavements close to shops or other commercial buildings such as cinema halls, discotheques and theatres. Some spend their nights at bus or railway terminals, and in corridors near religious institutions. Others especially girls spend their nights in hotels, brothels or as partners of night security guards. Street life predisposes the children to prostitution and crime. Lugalla and Mbwambo note that during the day these children rely on odd, menial occupations like car washing, baggage loading and begging (334-335) [27].

Marc Sommers [28] observes that in subSaharan Africa, urbanization goes hand in hand with slum growth with about $70 \%$ of the region's urban population living in slums. Save for the few individuals who have corruptly amassed wealth, majority of people in the fictional societies of the texts under study do not have decent habitat. In Dar es-Salaam by night, Mtobwa writes:

Hasira filled the pail with water and dragged himself to the bathroom. It was used communal by all the tenants. It served also as the latrine and was already nearly flowing over with human waste. Worms from the pit could be seen wriggling all over the floor. He placed the pail near the pit, hung his towel on the piece of sacking material that served as the door of the facility...(94).

The situation above is akin to what Kehinde observes in a study of Major Mwangi's urban fiction works. Kehinde notes that in Kill me Quick [4], the Shantytown where the deprived masses live is used as an objective and complex index of the characters and their material impoverishment (234). The generally squalid tenement of majority of the urban dwellers in Major Mwangi's urban novels and in Mtobwa's novels under this study directly point to a ubiquitous tone of disillusionment in the post-colonial urban space. It further points to a situation in which the ordinary citizenry encounter virtually everything that negates joy. Mtobwa presents this kind of setting to aid in the understanding of the socio-economic dynamics of the post-colonial urban space. The setting as used by the author in the texts under study alludes to a sense of socio-economic immobility on the part of the urban underclass. The street and slum life that the ordinary urbanites lead, considered against the affluent living conditions of the likes of Peterson or Kandili in his later life reflects the kind of cultural-cum-class differences pitting the majority poor and the minority elite.

The situation is real in Tanzanian urban areas as well as most post- colonial African cities. Parker (qtd in Sommers 17-33) describes the city of Lagos, Nigeria in a rather visceral manner remarking that, "It's hard to decide... if the extravagant ugliness of the cityscape is a sign of vigor or of disease." He concludes that the "... human misery of Lagos not only overwhelms one's senses and sympathy but also seems irreversible." Parker alludes to the apparent double-faced reality of the city space. The city is described as promising yet discouraging. The ordinary urbanite is unrelenting in the quest to survive in the city despite the harsh socioeconomic hardships.

Garth Myers in a survey of Dar es-Salaam, and Zanzibar in Tanzania ascribes the poor socio-economic state of affairs in Africa to multilateral institutions and donor governments, which have occasioned African governments' adoption of neoliberal economic policies and expansion of direct foreign investment (qtd in Sommers 319). Sommers share the view that this is significantly responsible for the economic inequalities in African cities. Myers concludes that in the Republic of Tanzania, "poverty has become more widespread and that local governments have lost their capacity to meet their responsibilities." African urban dwellers especially the poor, who are also the majority, have not been spared the problems of poor sanitation, water-related diseases and the HIV/AIDS pandemic. 
Population in African urban areas has remained on the increasing streak, with efforts to encourage rural settlement and urban-rural migration bearing no significant fruits. In 1983, for instance, the Republic of Tanzania gallantly engineered the "Nguvu Kazi" (Hard Work) campaign to return jobless youths to their rural homes. This exercise by the Tanzanian government failed drastically. This continued bulge in African urban population has also contributed in exacerbating the socio-economic constraints and hardships especially for the ordinary African urbanites (Sommers, 12-13). Employment in the formal sector is hard to come by particularly for the youth who constitute the biggest percentage of African urban population. Sommers, for instance, notes that Dar esSalaam is known to the youth in Tanzania as "Bongoland", the term "bongo" being slang for "brains". The implication of Dar es-Salaam's nickname is that one needs to be cunning, smart and witty to make it in the city-which ironically, is believed by the Tanzanian rural youth to be a place of extravagant wealth. Sommers concludes that many don't make it in "Bongoland" (Tanzania) because the competition is so fierce (323). Even for those who secure jobs, the salaries and wages given can hardly support a decent living. In Give me Money, Kandili Maulana is disappointed at the realization that his job can hardly sustain him. The salary is meager; the value of the money is depreciating even as the prices of essential commodities continue to rise.

According to Odhiambo, the post-colonial city "became an ambiguous space; offering opportunities for economic survival and improvement but also projecting an alien environment" (qtd. in Musangi 52). The city of Arusha as presented in Give me money is one of hardship and disappointment especially for the ordinary citizens. Workers at the factory suffer victimization and exploitation in the hands of a few individuals. Musangi notes that for the new African arrivals in the city there is a sense of ambivalence, with the new immigrant into the city finding the place to be a home that has a sense of homelessness (52). Musangi observes, for instance, that Nairobi is a city of suffering where people go through life as street urchins, prostitutes, or petty criminals when all is lost (53). Life in the city is full of social challenges for the ordinary citizen.

Kandili Maulana, the main character in Give me Money is among individuals who have finally secured employment at the Oxton factory. Workers at the factory continually grumble even as their bosses, already immersed in the vice of economic sabotage, completely turn a deaf ear to their genuine grievances. Dissenting voices are either compromised or silenced through all manner of ways. This is manifest in the ways the secretary-general of the workers union of the factory and the chairman are dealt with. The adamant secretary general is eventually killed by the corrupt doctor while undergoing treatment in hospital. The gap between the corrupt rich and the poor increasingly grows. Essential commodities like medicines, sugar, soap, salt, and flour among others are hoarded or exported even as people continue dying and the cost of living gets unbearable to the common man. Living standards in towns seem unbearable even for those in employment. The police, the magistrates and the media are all compromised. Gromov notes that at the height of dissent among the ordinary citizens, the government of Tanzania launched a belated crackdown on economic saboteurs (13-15). This however did not improve the situation for the urban underclass. Eradicating the vices in the society proved an uphill task and the citizens remained largely a disillusioned lot. Give me Money vividly reflects this atmosphere of disappointment and apathy among the ordinary citizens. Mtobwa notes thus:

Following the clampdown...commodities which had for a long time been scarce, began to reappear in the shops, selling at controlled prices... "Long live Nyerere!" people chanted...But the joy did not last long. It began to disappear gradually and finally it was no longer there. New complaints replaced the old hope (112).

The clampdown on economic saboteurs was not exhaustive enough...nor did it result in perceptive success. The evil corrupt deeds were still being committed and people still complained. The ordinary citizens lamented that people in high positions who were responsible for the crimes were yet to be netted. To make it worse, some arrested suspects were being released (114). Indeed, Kandili Maulana one of the chief architects of economic sabotage and the main character in Give me Money, escaped the crackdown.

In Dar es-Salaam by Night the setting is the Tanzanian city of Dar es-Salaam and a few other major towns like Mwanza. Night-life in the city of Dar esSalaam is vividly reflected in this text. Sommers observe that to the many immigrants into Dar essalaam, life presents a great deal of socio-economic hardship which at the same time is tempered with lots of intrigues, excitement, adventures and misadventures (17-33). Sommers notes that the youth in urban Tanzania are faced with lots of challenges including the overbearing temptation to immerse themselves in a variety of adventures and misadventures. Part of the youth challenges, as Sommers observes, includes a predisposition to a life of indulgence in practices like crime, drug abuse and prostitution-vices which characterize many post-colonial African urban cities, Dar es-Salaam included. The text, Dar es-Salaam by Night traverses several hotels, bars and clubs, painting a clear picture of what goes on in these places. At The Embassy Hotel, a top tourist hotel, a white man is seen surrounded by two African girls who caress him as he laughs. Mtobwa describes the ambience of the hotel as follows: 
"At one of the tables you see a man and a woman who strike you as a husband and wife; at another you see a man and a woman who strike you as a couple which has struck up a recent friendship. At yet another table you see a small crowd of men talking in undertones, and you are left in little doubt that they are making some secret plans, perhaps to smuggle something or to commit some criminal act"(20-21).

Rukia the main character is described as a drug addict and an accomplished prostitute. She has been forced into prostitution at a young age by her mother's wayward behavior. Her mother abandons her and elopes with a white man to Nairobi. Rukia is described as starved of food and gloomy-looking. She finds herself in the midst of harsh conditions of urban life with no one to turn to. Poverty and hunger strengthen the young girl's resolve to perfect the art of prostitution in order to survive the harsh city life. Rukia meets a wealthy elderly man in a club and falls in love with him. They engage in lots of sexual escapades which cover a big part of this text. Mtobwa presents a unique case of love a triangle pitting Rukia, Peterson and Hasara who, towards the end of the novel learn of their being born of the same biological mother. These acts of decadence smack of the urban underclass's search for survival means in the wake of intense socio-economic and political challenges. There is also a sense of desperation among the people-a situation which causes individuals to resort to indulgence as a form of escapism. Dar essalaam city and other major towns like Mwanza are said to be awash with nocturnal activities which include prostitution and crime. Black marketeers, saboteurs, prostitutes and confidence tricksters meet in night clubs as they indulge and take stoke of their shady deals (8). Mtobwa writes:

This night like all the rest found pleasureseekers in Dar es-salaam, old and young, at various night sports. Bars were noisy with drinkers. Dance-halls had their share of nocturnal crowds and the cinemas were just as lively. Prostitutes hung about the streets and the drinking places, crossing paths with nocturnal thieves and gangsters. Only the beggars huddled themselves in dark corners to remind humanity that sadness, loneliness and grief existed in the world (20).

The relationship between crime and prostitution on the one hand and disillusionment on the other is recognized by many literary artists and scholars. In Major Mwangi's Kill me Quick [4], for instance, the two main characters Maina and Meja having moved from their village to the city of Nairobi end up disappointed in town. The two boys, due to lack of employment end up in the streets of Nairobi and eventually in jail for vagrancy and petty crime. Ben and Ocholla in Major Mwangi's Going Down River Road take solace and delight in a life of sexual pleasure and moral decadence. Musangi (56) in a study of Major Mwangi's urban novels notes that no matter how much the characters seem to suffer and struggle in the city, they would rather face the city's uncertainty than go back to their villages. Ben and Ocholla in Going Down River Road [6], go through hardship, living in slums, going hungry most of the time. It seems inevitable that the two can only seek solace and comfort in sexual indulgence and drunkenness.

Mtobwa in Dar es-Salaam by Night uses the night to aptly depict a situation of "darkness", hopelessness and despair-a situation characterized by transgression against the traditional moral norms of the society. In the society depicted in the text, night time is depicted as (being) abuzz with activities of crime and sexual decadence. Tausi Social Hall, for instance, is said to be reputed for possessing "the ability to generate carefree rejoicing". The narration goes:

Take tonight's crowd...that woman over there appears to have thought it cruel for her man to sit on the steel chair and has decided to carry him on her lap like a baby...the man seems contented and smokes endlessly, almost oblivious of the beer that half-fills the glass in his left hand. Then there is a table surrounded by five people-four men and a woman. The woman seemed to have had her fill already...Look at how she caresses the chin of that while at the same time playing with the beard of the other (25).

In drunkenness and sexual indulgence, ordinary men and women find solace in the midst of the frustration that characterizes post-colonial urban life. As alluded to in other parts of this study, to the urbanites, the bar provides a forum for reprieve and an opportunity to temporarily nestle in escapism. In sexual and moral decadence, individuals derive a sense of relief which further provides them with the impetus to soldier on in the challenging dynamics of urban life. McKeown observes that urban literature other than performing other functions draws a sharp distinction between the boredom of rural life and the opportunities for entertainment offered by urban areas (122).

Hasira introduces Hasara to criminal deals. Their plan to kill Peterson does not materialize. He promises to take a pistol to Hasara and teach him how to use it (92). The adult Hasira is a hard-core criminal. Hasira is also an embittered man. He laments:

Do you know that these people are behaving like demi-gods? ...people who are really free in this country are very few...we are all their slaves, sweating day and night and spilling our 
blood for their benefit and that of their children and even concubines (90).

A close scrutiny of the range of activities taking place in the cities as presented in the text reveals an atmosphere and mood of intense frustration and disappointment in life.

In Give me Money majority of the citizens are powerless, impoverished and voiceless. Workers are exploited even as majority of citizens who have migrated to towns encounter the harsh reality of unemployment. Women too suffer silently as their children continue dying from the deadly disease, palala, whose medicine is hoarded by powerful economic saboteurs. The situation was compounded by the craze by the socio-political and economic elite in society to embrace and perpetuate the colonialist practice of capitalism. Under capitalism the post-colonial society in question was fast developing into one in which the resources were made accessible only to a minority group.

This study, therefore, cannot overemphasize the strong interplay that exists between setting in the texts Give me Money and Dar es-Salaam by Night on the one hand, and disillusionment as portrayed by the two texts.

\section{Disillusionment and Characterization in Give me Money and Dar es-Salaam by Night}

This sub-section begins by introducing the concept of character and characterization from the perspective of this study. Characterization is a literary device by means of which writers present and reveal characters in a text. A character is a form represented in a dramatic or narrative work, interpreted by the reader or audience as being endowed with particular moral, intellectual, and emotional qualities by inferences, based on the writer's manner of presentation. Characters are the media through which readers (or the audience) interact with literary works. A writer uses various ways and techniques in presenting a character. A writer may directly describe the character telling what the character is like. A writer may show the character's details such as dress, bearing or looks. A character may also be presented in action, and in interaction with other characters.

Souad defines two types of characterizationdirect characterization (which involves a direct description by the narrator in the text) and indirect characterization (13-17). Indirect characterization requires the reader or audience to understand the nature of the character by his/her (the character's) thought speech, appearance, role, action, and influence on other characters. Reams (15) notes that direct characterization "is best in identifying the core characteristics of an individual-the most important facets of who they are".
Characters can be distinguished as minor and major, or static and dynamic. A major character is the figure on which the text's central theme or action is centered. Kandili Maulana, Bon Kolo and Idrisa Kalulu are typical examples in Give me Money while Dar esSalaam by Night features Rukia, Peterson and Hasara as major characters. Minor characters serve to among other things, support and illuminate the major character. In Give me Money some of these include Dora, workers at the Oxton factory, Mtondolo, the doctor, the police, the suffering mothers and children among others. In Dar es-Salaam by Night some minor characters include the police, Peterson's secretary-Grace, Mama SonyPeterson's wife, Kautipe and Nuru among others. A static character virtually remains the same from the beginning of a text to the end. A dynamic character on the other hand, exhibits changes in terms of attitude, purpose or behavior as the story progresses. These changes may be as a result of crises or growth, development or maturity. Typical examples are Kandili Maulana and Rukia in Give me Money and Dar esSalaam by Night respectively.

Mtobwa has used a variety of ways to present to the reader the interaction between the characters in the texts, their social environment and the salient concerns of the texts. The author has, in both texts, given prominence to the anti-hero technique in conveying his central concerns which revolve around disillusionment. The protagonists in the two texts (Kandili and Rukia) lack the typical heroic qualities. Kandili is an agent of corruption, oppression and victimization. Rukia on the other hand thrives on prostitution. Give me Money features Kandili Maulana, Bon Kolo, Idrisa and Maua, individuals who met out atrocities to the ordinary citizens. In Dar es-Salaam by Night Rukia, Peterson and Hasira are by normal standards no heroic in character either. The use of antihero protagonists in the texts further underscores the extent of corruption and sleaze in the society in question.

Apart from direct description by the narrator, the author engages the characters in a variety of conversations, dialogues, and actions. Both texts are presented from the third- person omniscient point of view, presenting in-depth detail on the actions, thoughts and consciousness of the characters.

Kehinde [1] notes that the sociological approach in literary valuation suggests that "characters should be typical, that is, representing a class; for example, the insensitive bourgeois class, the oppressed downtrodden masses, and the agents of the state." The kind of relationship between the characters of high socio-economic class and the lowly ones presents an apparent interplay between disillusionment and characterization in the texts under study. 
The two texts aptly represent these categories of characters. In Give me Money, for instance, Mtobwa depicts Idrisa Kalulu and Bon Kolo as agents of exploitation and oppression. Kandili Maulana is also later incorporated into this category. Bon Kolo would stop at nothing to ensure he denies the innocent majority citizens their material entitlements for his selfish gain. He asks Kandili, 'What is the use of thinking of others while you yourself languish in poverty?' He is also boisterous, abrasive, cunning and sly. He beats up Kandili and even conspires with Idrisa to frame up Kandili in a bid to coerce him to give in and cooperate with them in their corrupt deals. He tells Kandili that the entire ordeal he underwent including his imprisonment, and the beatings by the militia-man had been deliberately planned (15).

The bourgeoisie are presented as consumerist and insensitive to the plight of the ordinary citizens. Bon Kolo is depicted as a flamboyant and extremely extravagant man. $\mathrm{He}$ is randy and promiscuous, a womanizer who is described as 'loaded with money every day, every hour and every minute. ' and ...is said to have 'put up an enormous mansion in an amazingly short time...' (6-7).

Idrisa Kalulu is the Managing Director of Toko, the Oxton manufacturing company in Arusha which is the only manufacturer of the drug, Oxton in the entire Africa. Idrisa is corrupt, wealthy and inhumane as well. He bribes the poor in order to secure a job for them. He is unkind and mistreats his workers. He's said to be inaccessible to his workers and would endlessly keep them waiting whenever they wanted to see him. He's a cruel, merciless man who sacked workers for mere trifles. He executes many of his atrocities by proxy, mostly using his confidante, Bon Kolo and Maua.

Kandili Maulana, the main character is presented as a dynamic character that rises from abject poverty to a life of massive wealth courtesy of his change from an honest person into an extremely corrupt individual. The texts under study have also depicted some characters as symbols of the oppressed, an uncertain future and destroyed hopes of a society in socio-economic misery. Kandili's earlier life in the rural Kwamtoro Village, Kondoa District in Dodoma Region is presented as miserable. He hails from a poor, large family headed by his widowed mother. In his memory of his childhood, '... he could see in his mind's eyes a dirty, nondescript child in tattered clothes that exposed his buttocks, going to school, his steps weak'(24). His siblings too wore rags and ate poor food-the kind of food which only filled the stomach (25). Among his fellow pupils he felt inferior, thinking his mates thought him unfit to be among them' (24).
In Dar es-Salaam by Night too, characterization has also been used to reflect the existence of the socio-economic dichotomy between the rich and the poor. The main characters in the text are Rukia, Peterson, Hasira and Hasara. Hasira and Hasara engage in several discourses which point to the extent of their disappointment in the social ills afflicting their society. Hasira, for instance says:

... They want us to continue licking their boots. They use every kind of trick to keep us trapped in this mire of poverty to deny us freedom...They advance themselves bank loans which they never pay back. They teach each other tricks to steal from the government and nobody intervenes (90-91).

Hasira, by many of his sentiments, appears embittered and no longer ready to continue serving the whims of the socio-economic elite in his society. He is also intent on sensitizing his fellows, the ordinary citizens to be wary of their plight and if possible rise up to the occasion by whatever means. It is worth noting that the name "Hasira" given to this character is a Swahili word for "anger". Hasira is not happy about what is going on in his society. He is not happy about the predicament of the ordinary citizens. He engages in a lot of lament and bitter comments regarding the way the lowly in his society are treated by the socioeconomic elite.

Peterson in Dar es-Salaam by Night, on the other hand, is presented as an extremely wealthy man. His house is described as cozy, equipped with the latest air-conditioning gadgets. There are two water pools, one for swimming and the other for rearing fish. His children were healthy, intelligent and attended the best schools. He represents the capitalist bourgeois class. The Continental Distribution Ltd. is a company in his ownership. He lives a lavish life, often presented as a patron in several social places like night clubs, bars and restaurants, hotels and lodgings. He meets and gets infatuated with Rukia, a lady much younger than him. Peterson hails from an affluent background and has inherited wealth from his deceased father.

Characterization has also been used to reflect the involvement of state agencies and government institutions in the vice of corruption. In Give me Money, when a commission of inquiry is set up to investigate the corrupt activities at the Oxton factory, the members of the commission are said to have been bribed by the factory's management headed by Idrisa Kalulu. The police, the media, the judiciary and the medical personnel are involved in corruption. The media fabricate a story to frame up and implicate Kamkanda in a criminal activity. The doctor is bribed into administering a drug that eventually kills Kamkanda while he was undergoing treatment from injuries afflicted to him by Bon Kolo and his accomplices. The police are said to be receiving bribes 
from the top officials of the Oxton factory which is headed by Idrisa Kalulu. Abiodun Alao (72-74) observes that there is a link between the power of politics and the corruption of wealth, on the one hand, and the negative role of some of the citizens on the other. Abiodun notes that the people endorse the agents of corruption and condone their practices for personal gain.

In Dar es-Salaam by Night, Peterson, for instance, is said to engage in numerous business deals some of which involve government officials (50-51). Hasira articulates the social malpractices of the corrupt socio-economic elite in many ways. Hasira remarks that they award themselves scholarship opportunities, make sure they have better medical facilities, and award themselves licences for the most lucrative businesses.

The society in question as depicted by characters in Give me money is one that does not reward genuine efforts. It is a society that is indifferent and repulsive to honesty. Kandili in his school life was a bright student. He, however, developed a mental breakdown before he could sit his final high-school education and join university. Kandili is presented as a victim of circumstances- one who in adulthood finds himself with the options of either honesty or dishonesty. He has to choose between sinking deeper into poverty and misery on the one hand, and yielding to the malevolent, corrupt demands of his employer on the other. He eventually opts for the latter. The sociopolitical realities around him seem to negate his conception of a right and just society. He makes several attempts at dismissing Kolo's efforts in wooing him (Kandili) to toe their line (of corruption). He finally gives in and quickly learns the norms of corruption. As a stores clerk in Toko, the Oxton manufacturing company in Arusha, Kandili had faced all manner of intimidation, oppression and blackmail under the leadership of Idrisa Kalulu the company's Managing Director and Bon Kolo. Idrisa uses Bon and Maua to bludgeon Kandili into joining their corruption bandwagon. Mtobwa writes:

Kandili was fully involved in the traffic although deep in his heart he would have preferred not to cooperate. Being told by Bon to think about his involvement was simply another way of his being told that he had no choice but to cooperate or else he would lose his job (which he loved and fully depended on) (33).

Kandili had gone through several ordeals before he eventually agreed to cooperate as a central accessory to the illicit deals at Toko Company. Kandili changes his character becoming one of the most corrupt individuals in his society. Mtobwa's construction of this character asserts the study's position that the difficult experiences one undergoes in life significantly inform one's subsequent decisions regarding life. Kandili Maulana's character is to a great extent shaped around disillusionment. His youth experiences transform him from an innocent man into an agent of corruption-one who perpetuates among his countrymen the very feelings of wanton disillusionment of which he had been a victim.

When Kandili begins to engage in the shady deals of economic sabotage, his socio-economic life suddenly changes. He soon becomes an extremely corrupt and wealthy man, owning a vast empire of businesses, most of which are registered under other people's names. Corruption seems to be rewarding in the society in question. This is a typical feature of characterization in urban fiction. The conventionally unacceptable traits thrive in the urban society courtesy of socio-economic challenges and other forms of survival-for-the-fittest realities encountered in the city. The tone in the urban fiction society, therefore, remains largely one in which characters derive success from embracing vices such as corruption and profanity.

Ben Mtobwa also uses some characters to represent individuals among the ordinary citizens of the real post-colonial Tanzanian society who are the voice of the suffering- brave, ordinary citizens championing the rights of the oppressed, pauperized workers and other citizens. In the midst of the society's deeplyrooted corruption, however, the efforts by a few individuals towards freeing themselves from oppression and exploitation do not seem to bear fruit. Kanda wa Kamkanda is the Oxton factory JUWATA secretary. He is described as a clever man. He urges his union chair Kombo Mtondolo to present the people's grievances to the Managing Director. He is an embittered, brave man. $\mathrm{He}$ is disillusioned as a result of the developments in his country. His parents had not been poor but his home had been razed down by arsonists and his parents tortured and eventually killed by the invading forces. The forces of Idi Amin invaded Tanzania and provoked the war just at the time that he was waiting for the results of his final secondary education. After the war with Uganda, Kamkanda returned home to be welcomed by yet another series of disappointments and the broken-heartedness of many of his countrymen. Kamkanda realizes that some people had during Tanzania's misfortunes resorted to exploiting the circumstances for their selfish ends. 'Hoarding, black marketeering, smuggling, theft of public property, corruption and other evils became the order of the day' (40). Kamkanda is a frustrated citizen who displays a genuine sense of patriotism. His personal resolve is to unrelentingly wage a war against economic sabotage in his country.

Kombo Mtondolo is the union chairperson. He is among personalities in the post-colonial society that betray the trust that the ordinary workers and citizens have bestowed on them. He sets out to fight for the 
rights of the workers who had elected him into the position of chair. As the chair of the workers' union at the Oxton factory, he is tasked with presenting the grievances of the workers before the company's top management. However, he displays selfishness and cowardice when he backs off by heeding to the Managing Director's instruction to him to take a leave and wait for a reward of a scholarship abroad. Betrayal by fellows results in more frustration, grumbling and disillusionment. Betrayal drives the ordinary citizens into despondency and apathy further dashing their hopes and reducing their options for self-emancipation and socio-economic freedom.

When the secretary of the workers' union, Kamkanda wa Kamkanda decides to confront the Toko Managing Director, Idrisa Kalulu, he is immediately served with a letter of dismissal. Kamkanda remains undeterred and further manages to intercept a crew that was illegally smuggling some essential commodities out of the country. In the ensuing battle, he is injured, and hospitalized and later killed in hospital. Kamkanda loses his life due to his unrelenting efforts towards championing the rights of the workers and citizens of low socio-economic status. Mtobwa juxtaposes antagonists with heroic traits against the anti-hero protagonists. The anti-hero reigns and, for the most part carries the day. The author presents the society as one in which non-heroic traits and practices like corruption thrive while any efforts to counter such traits are nipped in the bud. The voice of reason does not go far before it is completely blocked. Meanwhile the protagonist who is anti-heroic thrives throughout most of the text. This is a feature of popular literature. Urban fictional works like John Kiriamiti's My life in Crime, My life with a Criminal; Major Mwangi's Going Down River Road, for instance, are some texts in which the anti-hero protagonists are prominently featured. In these (urban literature) texts, true heroism has little space of survival if any.

Mtobwa gives female characters in the texts sex-related traits. They are also reflected as helpless and having very limited options for survival in the socioeconomically tough society. A number of female characters are presented as "sex objects." In Give me Money, Maua is a female character, a prostitute and a key accomplice to the corrupt, illegal deals of Kalulu, Bon and Kandili. Her name, "Maua" is a Swahili word for "flower". The name symbolizes physical beauty. She uses her body for personal material gain as well as for the benefit of the ill interests of her corrupt masters. Bon reveals to Kandili that Maua had deliberately been used to lay a trap for him. In further persuading Kandili to join them in their deals, Bon says, 'If all you want is Maua, I'll let you have her...' (16). The extent of Maua's sleaze is best displayed when she is sent by Idrisa Kalulu to convince the doctor to have Kamkanda (the union secretary-general) killed. She gives the poorly-paid medic a colossal sum of money and promises him her body. Mtobwa has been accused of misogynist depiction of rape scenes with the insinuation that the raped women (as presented in the case of Rukia in childhood) enjoy infliction of pain (Mabala 40). However, this study argues that Mtobwa uses Rukia to reflect the social environment in which the urban youth especially the females grow, their state of helplessness in the circumstances they find themselves in, the predispositions they are subjected to, and their limited options for survival in the urban settings. Etyang notes that urban poverty is not just a collection of characteristics but it is also a dynamic condition of vulnerability or susceptibility to risks (2). Rukia's presentation is also a case of resilience and determination in the midst of socio-economic adversity. She perfects the practice of prostitution especially after her mother's departure to Nairobi. Rukia is said to have been pushed into prostitution by her poor background. Circumstances had driven her into prostitution at a very young age. Rukia's mother was a prostitute. Mtobwa writes: Suppose she gave consideration to her age: what would she eat? For three days now her tummy had known no food. Her mother had again run away deserting her. And this time she (Rukia) had despaired... (3). Rukia ponders:

Now that her mother was no more with her, the time had come to advertise her experience and silence those who regarded her as a child. It was an absolute necessity if she was to make a living. The mere four years of primary education she had received would not get her anywhere. Had those with a better education found jobs? And even if she was to be lucky enough...how would the minimum wage help her when those in high income brackets were going to bed hungry? (4).

The environment can be said to have been at play, informing the trajectory taken by a majority of characters in the texts under study. Rukia is a typical case in point. In Mangua's Son of a Woman [9], Dodge Kiunyu, the main character, just like Rukia, was born of a prostitute mother, Theresa Ngendo. Kiunyu gets married to Tonia, also a prostitute who engages in commercial sex activities together with her mother. The prostitute motif is important in advancing the major thematic concerns in urban fiction. In Going Down River Road, Ocholla on being fired from his job seeks solace in a bar where he meets a prostitute with whom he starts living in the squalid residence similar to his.

Virtually all other characters have, somehow or other, been constructed around the phenomenon of post-colonial disillusionment. In Give me Money, mothers are said to live in poverty and a life full of tears especially as they helplessly watch their children die of starvation and curable diseases. This happens courtesy of the activities of economic saboteurs who have made essential commodities inaccessible to the common man. 
Dora is forced into prostitution as a result of frustration and disappointment in life. The rural folk in the villages suffer abject poverty. This is illustrated in the portrayal of the rural home of Hasira.

It is not only the poor who experience disillusionment. Women married to wealthy men, for instance, are presented as living a life of frustration. In Dar es-salaam by Night, for instance, Peterson's wife despite having material wealth is deprived of love from her husband. She perseveres with living with an unfaithful husband who shows her no love. Peterson's secretary, Grace tells her boss, "Excuse me sir...I forgot to inform you that your wife, Mama Sony, has been ringing for the past two days asking for you" (106). Peterson in response wonders, "What does she want?" $\mathrm{He}$ gives an excuse, "Tell her I'm on a business trip...Tell her some urgent business summon has taken me to Nairobi and that on my way back I'll call in Zanzibar" (107). Peterson is an absentee husband who delights in extra-marital relationship.

Another remarkable feature of Mtobwa's characterization in these texts is seen in the way he significantly attempts to invite the readers to see the world from the perspective of the youth and children. In Dar es-Salaam by Night, the early lives of Rukia, Hasara, Hasira and other youth are given considerable prominence in this text. Mtobwa realistically presents the youth and the hardships they undergo especially in their quest to improve their lives in the urban space. Children are not spared the socio-economic experiences and challenges facing their society. Mtobwa uses the device of flashback, in such a way that the reader can understand the background history of the characters. The characters are presented as self- aware of the largely misfortune-marred nuances of their formative years. Hasira and Hasara, for instance are cognizant of the inequities in their society. Hasira's early life revolves around the streets. His name means temper (or anger). He was the leader of a street gang. His life and that of his companions is described as one of dirty, poor children who lived on picking dumped left-over food from dustbins. He is used to depict disillusionment that characterizes street life and how extremely low socioeconomic circumstances drive certain individuals in criminal activities. Hasira like many members of the street gang are said to have moved away from his rural home in search of a better livelihood but he finds himself in the town streets. Faced with severe economic hardships, many citizens find themselves engaged in crime in order to survive. Hasira, for instance, rises from poverty to wealth by engaging in criminal and illegitimate activities. He at one point engages in a mission to have Peterson killed at all costs. Hasira in adulthood manages to acquire a considerable amount of wealth. He persuades his childhood friend Hasara to join him in his criminal activities if he wants to deliver himself from his life of misery. Hasira's life well exemplifies the relentless struggle and craving of the ordinary man to survive in the midst of the hardships of post-colonial urban life. The sociological approach to literature concerns itself with literature and its reflection of humans, their lives, activities and struggles in society. The sociological literary criticism investigates how mankind operates and persists in society. Mtobwa conveys a message to the effect that a considerable section of the urban underclass, particularly remains determined to survive in the urban space. There is also a sense of ambivalence on the part of the ordinary urban dweller over the state of affairs in the post-colonial urban society. As already noted, to some individuals, the metropolis offers a golden opportunity for socioeconomic prosperity and escape from rural poverty. Ikone Chidi et al.posits that the massive incursion of people into urban areas is as a result of sudden new tastes and wants which only the city can offer (qtd. in Etyang 22).

Hasara like Hasira spent his childhood on the streets. His name is a Swahili word for "loss" Mtobwa writes of Hasara, "He felt life had been unfair to him. How humiliating it had been to be so scantily dressed and sleep out in the open... Anger ruled his heart. He was full of indignation at the entire mankind' (42). The narrator goes on to say"

To him the world had been created good. God had intended people to be equal, but somewhere had gone wrong....He had heard it said so many times that the best anti-dote to inequalities was socialism. Yet even under socialism only a few seemed to benefit while the masses were condemned to suffering (133).

In Dar es-Salaam by Night Rukia who is abandoned by her mother at a tender age doesn't know her father either. Peterson does not know his mother and neither does Hasara know his parents. Rukia though a young girl becomes infatuated with Peterson, a relatively older man. The urban space and its complexities offer a break with traditional societal value systems. In a harsh life of survival-for-the- fittest in the metropolis where competition for financial freedom is stiff, individuals throw caution to the wind, in a quest to make it in life. The female gender is the most vulnerable in this situation. Rukia is therefore, desperately in need of one who would deliver her from her poverty and economically uplift her.

When she first saw him she had fallen for him after seeing the way he ordered beers: It was as if he had all the money in the world. And not only beer: he would order roast chicken now and again and generously tip the bar-maids. Rukia had thought a man like that would satisfy her lust for money (2). 
Rukia's socio-economic life soon improves courtesy of Peterson and other men who pay her for sexual services. She owns a car and a big house.

Towards the end of the text, however, Peterson and Rukia discover that they are actually brother and sister born of the same mother but different fathers. Their love lives are shattered. Rukia's anticipated wedding to Hasira cannot proceed. Peterson is ashamed of his past relationship with Rukia. These three characters seem to mediate a situation of hopelessness, desperation and intense rot in the society-a situation in which there aren't the slightest traces of solution to the socio-economic conflicts afflicting the society.

\section{Disillusionment and Thematic Concerns in Give me Money and Dar es-Salaam by Night}

This sub-section looks at the interplay between disillusionment and thematic concerns addressed in the texts under study. The sub-section begins with a brief definition of "theme" as used in this study. Theme in Literature refers to the main ideas or underlying meanings in a literary text. A literary work may have major themes and minor themes (Souad 11-16). A major theme dominates and prevails in a text while minor themes are ideas that only appear occasionally in a text. Typically, writers express themes by means of exposing the thoughts and feelings of the characters especially the main character; utterances and conversations among characters; lessons learnt especially by the main character in the text; and the actions or events in the story and their possible implications.

Loomba (4) notes that post-colonialism, among other things, identifies social inequalities as an issue of concern in post-colonial societies. She further notes that post-colonialism aims to challenge the structural inequalities in society and bring about social justice. The inequalities result in myriad socioeconomic and political problems which the postcolonial African society continues to grapple with. Give me money and Dar es-Salaam by Night, like many postcolonial African urban novels present a nation whose ordinary citizens are in socio-economic woe. The themes addressed in these texts include rampant corruption in society, economic sabotage activities; class difference and socio-economic disparity between the poor and the rich; street life and crime, prostitution and moral decadence; oppression and exploitation of workers and ordinary citizens. The texts foreground such social ills as corrupt employment processes, insensate dispensation of justice by the arms of the state charged with the responsibility, deplorable social services, and imprudent use of sex for financial gain and sexual harassment.
Rampant corruption and greed in society, and its psychological and social impact on the ordinary citizens

One common theme of post-colonial texts from Africa is corruption by the ruling socio-economic elite. A notable case in point is Chinua Achebe's A Man of the People, a novel which satirizes and problematizes the re-shaped African society, casting a deep reflection on the emerging modern Africa with its multi-faceted challenges and experiences of growth and degeneration. The researcher of this study draws parallels between $A$ Man of the People and Mtobwa's texts in question. Corruption is at an alarming proportion in the societies represented in the texts in Give me Money and Dar esSalaam by Night. In Give me Money, the top management of the Oxton manufacturing factory are the main perpetrators of corruption. Led by Idrisa Kalulu this cartel of drug barons symbolizes the socioeconomic elite in the post-colonial society. This group practices brazen corruption. The elite work with relevant government agencies to execute their shady deals. By implicating the government in this state of affairs, Mtobwa problematizes the society's governance systems presenting the state not only as complicit in the vice of corruption, but also incompetent and insensitive to the plight of its citizens. The administrative and political class entirely comprising indigenous Africans is reflected as both socially and technically inept. Incompetence and lack of political will aids in the increase of corruption in society. It is only towards the end of the text after the ordinary citizen has suffered, after several deaths and after intense complaints and grumbling by the citizenry that the government purportedly swung into action. The crackdown by the government on corrupt cartels and economic saboteurs does not bear significant fruits either. Oxton is said to be a very rare medicine for curing the deadly disease Pallala. Toko is the only African factory producing this drug. Idrisa, the company's Managing Director however, capitalizes on this situation to export and hoard Oxton and thus deny the citizens this essential commodity.

Idrisa Kalulu, the infamous Managing Director of the Oxton factory finally bribes his way into politics. He is elected a Member of Parliament and appointed Minister of Human Rights. Corruption seems to have reached uncontrollable proportions in the society in question. This is a replica of what takes place in many post-colonial African states. Macheka, for instance, notes that almost everyone in independent African society is engrossed in corrupt practices. In his study of Chinua Achebe's A Man of the People, Macheka notes that Odili, who appears to be an antithesis of Nanga-and who, in fact, is critical of Chief Nanga is also hypocritical and corrupt (16). Odili in one instance of corruption uses C.P.C. money to cover his father's case of Tax Assessment Office and pays the bride price for his promised wife. Max, who is in agreement with Odili on the need to rid the country of 
corruption, also accepts money from the communist party and from Chief Koko. The extent of corruption in many post-colonial African states is such that the ordinary citizens are vulnerable and predisposed to an overbearing temptation to jump ship and join the corruption bandwagon. Ayi Kwei Arma's The Beautiful Ones are Not yet Born presents an indictment of the institutionalization and universalization of corruption and bribery in the Ghanaian society. Corruption is seen as the only means to socio-economic prosperity. In Dar es-Salaam by Night, Mtobwa in reference to Peterson writes:

He had seen some politicians preach equality during the day and pursue their acquisitive ends during the night.... He did not think the country's better than those of the countries he had been to... What kind of policies were these that closed people's eyes, made them clap with joy at some lofty ideal while the people who preached the ideal knew just what they wanted and got it? (75).

Peterson is conscious of the ills and inequalities in his society. Mtobwa writes that it had not taken Peterson long to realize that his education was not very useful in the society. Peterson had, in fact, begun to think that the time he had spent abroad studying was a waste of time (74). The narrator goes on:

He (Peterson) had come to realize that what mattered in the country was who you knew. It was a matter of "technical know who" and not "technical know-how". Knowing people who mattered and having them know you was more important than the paper qualifications (74).

Hasira and Hasara are constantly engaged in lament regarding the corrupt practices of government officials and the entire socio-economic elite. Hasara expresses a feeling of betrayal, frustration and disillusionment. Money and power seem to be revered in the society in question. The system supports the corrupt and the wealthy in society. The emergent African elitist class that had replaced Europeans is insensitive and completely at odds with the general ordinary population. Mtobwa presents a clear-cut conflict pitting the affluent in society on the one hand and the lowly on the other. The latter are a weaker voice-an oppressed lot of citizens who can only whine in hushed tones with no one to listen to their predicament.

\section{Poverty, class stratification, economic disparity and their impact on the urban society}

The themes of poverty, class difference, and economic disparity among citizens are also reflected in the texts under study. Myers takes a post-colonial perspective with regard to the socio-economic state of affairs in the African urban space. Myers notes that post- colonial cities have not made much progress in overcoming the colonial past. He notes for instance:

Changes to planning laws, building rules, the structures of the world economy, the national urban hierarchy, and political processes at urban and national levels, spatial divides and the character of racism are not going to occur overnight, if they are even possible. Still, if African cities have indeed been attempting to subvert or eliminate the colonial legacies over these post-colonial decades, one is fairly often hard-pressed to see the result (34).

In Give me Money, the theme of poverty is portrayed through several characters. The text presents a majority of the citizens as languishing in poverty, and children dying of diseases and hunger. The theme of poverty among citizens is related to disillusionment. The theme of class difference is also prominently featured in the two texts. Kehinde notes that one of the problems of post-colonial betrayal in African nations is the insatiable quest for wealth by the indigenous sociopolitical elite (235). For lack of opportunity to compete with the rich on a fair footing, the masses get increasingly poorer. This problem finds expression in the two texts under study. In Give me money there is a sharp socio-economic disparity between the likes of Idrisa, Bon, Kandili on the one hand, and Kamkanda, workers at Toko and majority citizens who wallow in poverty and disease on the other. There is socioeconomic class difference between the minority elite and the majority urban underclass.

The same scenario is presented in Dar esSalaam by Night in the extremely affluent life of Peterson on the one hand, and the street lives of Hasara and many other children and adults. The urban majority are frustrated by this state of affairs. The quest for wealth and other forms of material gain has divided the society. There is a wide dichotomy between the rich and the poor. The rich use all manner of corrupt means to amass wealth as the poor languish and sink deeper in poverty. The socio-economic elite are insensitive to the plight of the common man. This is to a great extent due to capitalism and consumerism-systems or practices which can be ascribed to the interaction between Africa and European colonialist. Bon Kolo convinces Kandili to believe that he doesn't have to mind about others, so long as he (Kandili) was gaining from the shady deals. As a result, the urban society remains largely one in which the majority remains confined if not consigned to a miserable life characterized by poverty, unemployment, squalid living and a general lack of basic social amenities. Dar es-Salaam by Night vividly captures the street life in urban Tanzania featuring Hasira, Hasara and their counterparts. 
Children fought for food with stray dogs and cats. They fought amongst themselves too, something that sowed seeds of hatred and suspicion among them. Hasara... remembered how

Hasira had one day broken him a slice of dry bread out of pity. The bread was nearing decay but it was at least something with which to allay the hunger in his stomach (9).

Argo comments that generally, postindependence Africa is faced with a horizontal rift separating the elite from the masses [2]. Kehinde further observes that the African society is engulfed in poverty (231). He notes that the wealth is in the hands of a privileged minority which surrounds itself with country houses, cars, washing machines, television sets and all the consumer durables associated with an acquisitive middle class (231).

\section{The causes of crime, incest, prostitution and moral decadence in the urban society}

Dar es-Salaam by Night vividly reflects the magnitude of prostitution and moral decadence in the night-clubs and hotels of the city of Dar es-Salaam. The text portrays a situation of moral degradation and disintegration. This situation can be traceable to the colonial period. It is a reflection of moral confusion and chaos. It is a society marred by breakdown of traditional moral values.

The prostitution motif is prevalent in many urban literary works. In Major Mwangi's Going Down River Road, Ben and Ocholla seek solace in alcohol and women in the midst of socio-economic hardship in the urban space. The society in question seems to relegate the female gender to the periphery. Women are "objectified", and only given inferior, subsidiary roles. In several instances they are also presented as evilminded. Idrisa and Bon in Give me Money use Maua to execute several atrocities. She is used as bait to "coerce" Kandili to join the corruption bandwagon of Idrisa and Bon. Maua is sent by Idrisa to entice the doctor with money and a promise of her body in order to have him administer a drug which eventually kills Kamkanda while undergoing treatment in hospital.

Kurtz traces the relegation of women in the post-colonial urban space to the period of European colonization of Africa. He notes that in the white colonial administration, Africans had been considered temporary residents in the cities. Men had not been allowed to bring their families into the cities. African women had been considered a menace whose role was to 'immoralize' the urban male and the urban space [18]. This study argues that this patriarchal stance by the colonial powers was significantly responsible for the experiences women and the female gender at large were undergoing in the post-colonial urban space in
Africa. The notion of male domination and virtual feminine absence in the urban space was being perpetuated in the post-colonial era. Maua and Dora are presented as prostitutes. Maua is said to allow her body to be used as bait for financial gain. She like Rukia in Dar es-Salaam by Night is presented as a beautiful lady, a prostitute whose main expertise lies in offering sexual pleasure to many men.

Musangi underscores the significance of the bar in the post-colonial urban space. She notes that the bar is not only for the criminal but for most other urbanites whether in times of pleasure or adversity (68). Graebner notes that the bar is important to the urban dwellers not only for alcohol consumption but also because bars are the normal context of prostitution-the normal places where prostitutes and their male counterparts can meet and strike out their deals [18].

The perspective from which Mtobwa presents women can be said to be largely patriarchal. The society in question seems to expect women to look up to men as their superiors, and the only determinants of their livelihoods. They are expected to serve the whims of men. The presentation of women especially in urban literature texts exemplifies

Mtobwa in Dar es-Salaam by Night uses the night to aptly depict a situation of "darkness", hopelessness and despair-a situation characterized by transgression against the traditional moral norms of the society. In the society depicted in the text, night time is depicted as (being) abuzz with activities of crime and sexual decadence. Tausi Social Hall, for instance, is said to be reputed for possessing "the ability to generate carefree rejoicing". The narration goes:

Take tonight's crowd...that woman over there appears to have thought it cruel for her man to sit on the steel chair and has decided to carry him on her lap like a baby...the man seems contented and smokes endlessly, almost oblivious of the beer that half-fills the glass in his left hand. Then there is a table surrounded by five people-four men and a woman. The woman seemed to have had her fill already...Look at how she caresses the chin of that while at the same time playing with the beard of the other (25).

In drunkenness and sexual indulgence, ordinary men and women find solace in the midst of the frustration that characterizes post-colonial urban life. As alluded to in other parts of this study, to the urbanites, the bar provides a forum for reprieve and an opportunity to temporarily nestle in escapism. In sexual and moral decadence, individuals derive a sense of relief which further provides them with the impetus to soldier on in the challenging dynamics of urban life. 
McKeown observes that urban literature other than performing other functions draws a sharp distinction between the boredom of rural life and the opportunities for entertainment offered by urban areas (122).

Hasira introduces Hasara to criminal deals. Their plan to kill Peterson does not materialize. He promises to take a pistol to Hasara and teach him how to use it (92). The adult Hasira is a hard-core criminal. Hasira is also an embittered man. He laments:

Do you know that these people are behaving like demi-gods? ...people who are really free in this country are very few...we are all their slaves, sweating day and night and spilling our blood for their benefit and that of their children and even concubines (90).

A close scrutiny of the range of activities taking place in the cities as presented in the text reveals an atmosphere and mood of intense frustration and disappointment in life.

In Give me Money majority of the citizens are powerless, impoverished and voiceless. Workers are exploited even as majority of citizens who have migrated to towns encounter the harsh reality of unemployment. Women too suffer silently as their children continue dying from the deadly disease, palala, whose medicine is hoarded by powerful economic saboteurs. The situation was compounded by the craze by the socio-political and economic elite in society to embrace and perpetuate the colonialist practice of capitalism. Under capitalism the post-colonial society in question was fast developing into one in which the resources were made accessible only to a minority group.

This study, therefore, cannot overemphasize the strong interplay that exists between setting in the texts Give me Money and Dar es-Salaam by Night on the one hand, and disillusionment as portrayed by the two texts.

\section{Disillusionment and Characterization in Give me Money and Dar es-Salaam by Night}

This sub-section begins by introducing the concept of character and characterization from the perspective of this study. Characterization is a literary device by means of which writers present and reveal characters in a text. A character is a form represented in a dramatic or narrative work, interpreted by the reader or audience as being endowed with particular moral, intellectual, and emotional qualities by inferences, based on the writer's manner of presentation. Characters are the media through which readers (or the audience) interact with literary works. A writer uses various ways and techniques in presenting a character. A writer may directly describe the character telling what the character is like. A writer may show the character's details such as dress, bearing or looks. A character may also be presented in action, and in interaction with other characters.

Souad defines two types of characterizationdirect characterization (which involves a direct description by the narrator in the text) and indirect characterization (13-17). Indirect characterization requires the reader or audience to understand the nature of the character by his/her (the characters) thought speech, appearance, role, action, and influence on other characters. Reams (15) note that direct characterization "is best in identifying the core characteristics of an individual-the most important facets of who they are".

Characters can be distinguished as minor and major, or static and dynamic. A major character is the figure on which the text's central theme or action is centered. Kandili Maulana, Bon Kolo and Idrisa Kalulu are typical examples in Give me Money while Dar esSalaam by Night features Rukia, Peterson and Hasara as major characters. Minor characters serve to among other things, support and illuminate the major character. In Give me Money some of these include Dora, workers at the Oxton factory, Mtondolo, the doctor, the police, the suffering mothers and children among others. In Dar es-Salaam by Night some minor characters include the police, Peterson's secretary-Grace, Mama SonyPeterson's wife, Kautipe and Nuru among others. A static character virtually remains the same from the beginning of a text to the end. A dynamic character on the other hand, exhibits changes in terms of attitude, purpose or behavior as the story progresses. These changes may be as a result of crises or growth, development or maturity. Typical examples are Kandili Maulana and Rukia in Give me Money and Dar esSalaam by Night respectively.

Mtobwa has used a variety of ways to present to the reader the interaction between the characters in the texts, their social environment and the salient concerns of the texts. The author has, in both texts, given prominence to the anti-hero technique in conveying his central concerns which revolve around disillusionment. The protagonists in the two texts (Kandili and Rukia) lack the typical heroic qualities. Kandili is an agent of corruption, oppression and victimization. Rukia on the other hand thrives on prostitution. Give me Money features Kandili Maulana, Bon Kolo, Idrisa and Maua, individuals who met out atrocities to the ordinary citizens. In Dar es-Salaam by Night Rukia, Peterson and Hasira are by normal standards no heroic in character either. The use of antihero protagonists in the texts further underscores the extent of corruption and sleaze in the society in question.

Apart from direct description by the narrator, the author engages the characters in a variety of conversations, dialogues, and actions. Both texts are 
presented from the third- person omniscient point of view, presenting in-depth detail on the actions, thoughts and consciousness of the characters.

Kehinde [1] notes that the sociological approach in literary valuation suggests that "characters should be typical, that is, representing a class; for example, the insensitive bourgeois class, the oppressed downtrodden masses, and the agents of the state." The kind of relationship between the characters of high socio-economic class and the lowly ones presents an apparent interplay between disillusionment and characterization in the texts under study.

The two texts aptly represent these categories of characters. In Give me Money, for instance, Mtobwa depicts Idrisa Kalulu and Bon Kolo as agents of exploitation and oppression. Kandili Maulana is also later incorporated into this category. Bon Kolo would stop at nothing to ensure he denies the innocent majority citizens their material entitlements for his selfish gain. He asks Kandili, "What is the use of thinking of others while you yourself languish in poverty?' He is also boisterous, abrasive, cunning and sly. He beats up Kandili and even conspires with Idrisa to frame up Kandili in a bid to coerce him to give in and cooperate with them in their corrupt deals. He tells Kandili that the entire ordeal he underwent including his imprisonment, and the beatings by the militia-man had been deliberately planned (15).

The bourgeoisie are presented as consumerist and insensitive to the plight of the ordinary citizens. Bon Kolo is depicted as a flamboyant and extremely extravagant man. He is randy and promiscuous, a womanizer who is described as 'loaded with money every day, every hour and every minute. ' and ...is said to have 'put up an enormous mansion in an amazingly short time...' (6-7).

Idrisa Kalulu is the Managing Director of Toko, the Oxton manufacturing company in Arusha which is the only manufacturer of the drug, Oxton in the entire Africa. Idrisa is corrupt, wealthy and inhumane as well. He bribes the poor in order to secure a job for them. He is unkind and mistreats his workers. He's said to be inaccessible to his workers and would endlessly keep them waiting whenever they wanted to see him. He's a cruel, merciless man who sacked workers for mere trifles. He executes many of his atrocities by proxy, mostly using his confidante, Bon Kolo and Maua.

Kandili Maulana, the main character is presented as a dynamic character that rises from abject poverty to a life of massive wealth courtesy of his change from an honest person into an extremely corrupt individual. The texts under study have also depicted some characters as symbols of the oppressed, an uncertain future and destroyed hopes of a society in socio-economic misery. Kandili's earlier life in the rural Kwamtoro Village, Kondoa District in Dodoma Region is presented as miserable. He hails from a poor, large family headed by his widowed mother. In his memory of his childhood, '...he could see in his mind's eyes a dirty, nondescript child in tattered clothes that exposed his buttocks, going to school, his steps weak'(24). His siblings too wore rags and ate poor food-the kind of food which only filled the stomach (25). Among his fellow pupils he felt inferior, thinking his mates thought him unfit to be among them' (24).

In Dar es-Salaam by Night too, characterization has also been used to reflect the existence of the socio-economic dichotomy between the rich and the poor. The main characters in the text are Rukia, Peterson, Hasira and Hasara. Hasira and Hasara engage in several discourses which point to the extent of their disappointment in the social ills afflicting their society. Hasira, for instance says:

... They want us to continue licking their boots. They use every kind of trick to keep us trapped in this mire of poverty to deny us freedom...They advance themselves bank loans which they never pay back. They teach each other tricks to steal from the government and nobody intervenes (90-91).

Hasira, by many of his sentiments, appears embittered and no longer ready to continue serving the whims of the socio-economic elite in his society. He is also intent on sensitizing his fellows, the ordinary citizens to be wary of their plight and if possible rise up to the occasion by whatever means. It is worth noting that the name "Hasira" given to this character is a Swahili word for "anger". Hasira is not happy about what is going on in his society. He is not happy about the predicament of the ordinary citizens. He engages in a lot of lament and bitter comments regarding the way the lowly in his society are treated by the socioeconomic elite.

Peterson in Dar es-Salaam by Night, on the other hand, is presented as an extremely wealthy man. His house is described as cozy, equipped with the latest air-conditioning gadgets. There are two water pools, one for swimming and the other for rearing fish. His children were healthy, intelligent and attended the best schools. He represents the capitalist bourgeois class. The Continental Distribution Ltd. is a company in his ownership. He lives a lavish life, often presented as a patron in several social places like night clubs, bars and restaurants, hotels and lodgings. He meets and gets infatuated with Rukia, a lady much younger than him. Peterson hails from an affluent background and has inherited wealth from his deceased father. 
Characterization has also been used to reflect the involvement of state agencies and government institutions in the vice of corruption. In Give me Money, when a commission of inquiry is set up to investigate the corrupt activities at the Oxton factory, the members of the commission are said to have been bribed by the factory's management headed by Idrisa Kalulu. The police, the media, the judiciary and the medical personnel are involved in corruption. The media fabricate a story to frame up and implicate Kamkanda in a criminal activity. The doctor is bribed into administering a drug that eventually kills Kamkanda while he was undergoing treatment from injuries afflicted to him by Bon Kolo and his accomplices. The police are said to be receiving bribes from the top officials of the Oxton factory which is headed by Idrisa Kalulu. Abiodun Alao [19] observes that there is a link between the power of politics and the corruption of wealth, on the one hand, and the negative role of some of the citizens on the other. Abiodun notes that the people endorse the agents of corruption and condone their practices for personal gain.

In Dar es-Salaam by Night, Peterson, for instance, is said to engage in numerous business deals some of which involve government officials (50-51). Hasira articulates the social malpractices of the corrupt socio-economic elite in many ways. Hasira remarks that they award themselves scholarship opportunities, make sure they have better medical facilities, and award themselves licences for the most lucrative businesses.

The society in question as depicted by characters in Give me money is one that does not reward genuine efforts. It is a society that is indifferent and repulsive to honesty. Kandili in his school life was a bright student. He, however, developed a mental breakdown before he could sit his final high-school education and join university. Kandili is presented as a victim of circumstances- one who in adulthood finds himself with the options of either honesty or dishonesty. He has to choose between sinking deeper into poverty and misery on the one hand, and yielding to the malevolent, corrupt demands of his employer on the other. He eventually opts for the latter. The sociopolitical realities around him seem to negate his conception of a right and just society. He makes several attempts at dismissing Kolo's efforts in wooing him (Kandili) to toe their line (of corruption). He finally gives in and quickly learns the norms of corruption. As a stores clerk in Toko, the Oxton manufacturing company in Arusha, Kandili had faced all manner of intimidation, oppression and blackmail under the leadership of Idrisa Kalulu the company's Managing Director and Bon Kolo. Idrisa uses Bon and Maua to bludgeon Kandili into joining their corruption bandwagon. Mtobwa writes:
Kandili was fully involved in the traffic although deep in his heart he would have preferred not to cooperate. Being told by Bon to think about his involvement was simply another way of his being told that he had no choice but to cooperate or else he would lose his job (which he loved and fully depended on) (33).

Kandili had gone through several ordeals before he eventually agreed to cooperate as a central accessory to the illicit deals at Toko Company. Kandili changes his character becoming one of the most corrupt individuals in his society. Mtobwa's construction of this character asserts the study's position that the difficult experiences one undergoes in life significantly inform one's subsequent decisions regarding life. Kandili Maulana's character is to a great extent shaped around disillusionment. His youth experiences transform him from an innocent man into an agent of corruption-one who perpetuates among his countrymen the very feelings of wanton disillusionment of which he had been a victim.

When Kandili begins to engage in the shady deals of economic sabotage, his socio-economic life suddenly changes. He soon becomes an extremely corrupt and wealthy man, owning a vast empire of businesses, most of which are registered under other people's names. Corruption seems to be rewarding in the society in question. This is a typical feature of characterization in urban fiction. The conventionally unacceptable traits thrive in the urban society courtesy of socio-economic challenges and other forms of survival-for-the-fittest realities encountered in the city. The tone in the urban fiction society, therefore, remains largely one in which characters derive success from embracing vices such as corruption and profanity.

Ben Mtobwa also uses some characters to represent individuals among the ordinary citizens of the real post-colonial Tanzanian society who are the voice of the suffering- brave, ordinary citizens championing the rights of the oppressed, pauperized workers and other citizens. In the midst of the society's deeplyrooted corruption, however, the efforts by a few individuals towards freeing themselves from oppression and exploitation do not seem to bear fruit. Kanda wa Kamkanda is the Oxton factory JUWATA secretary. He is described as a clever man. He urges his union chair Kombo Mtondolo to present the people's grievances to the Managing Director. He is an embittered, brave man. $\mathrm{He}$ is disillusioned as a result of the developments in his country. His parents had not been poor but his home had been razed down by arsonists and his parents tortured and eventually killed by the invading forces. The forces of Idi Amin invaded Tanzania and provoked the war just at the time that he was waiting for the results of his final secondary education. After the war with Uganda, Kamkanda returned home to be 
welcomed by yet another series of disappointments and the broken-heartedness of many of his countrymen. Kamkanda realizes that some people had during Tanzania's misfortunes resorted to exploiting the circumstances for their selfish ends. 'Hoarding, black marketeering, smuggling, theft of public property, corruption and other evils became the order of the day' (40). Kamkanda is a frustrated citizen who displays a genuine sense of patriotism. His personal resolve is to unrelentingly wage a war against economic sabotage in his country.

Kombo Mtondolo is the union chairperson. He is among personalities in the post-colonial society that betray the trust that the ordinary workers and citizens have bestowed on them. He sets out to fight for the rights of the workers who had elected him into the position of chair. As the chair of the workers' union at the Oxton factory, he is tasked with presenting the grievances of the workers before the company's top management. However, he displays selfishness and cowardice when he backs off by heeding to the Managing Director's instruction to him to take a leave and wait for a reward of a scholarship abroad. Betrayal by fellows results in more frustration, grumbling and disillusionment. Betrayal drives the ordinary citizens into despondency and apathy further dashing their hopes and reducing their options for self-emancipation and socio-economic freedom.

When the secretary of the workers' union, Kamkanda wa Kamkanda decides to confront the Toko Managing Director, Idrisa Kalulu, he is immediately served with a letter of dismissal. Kamkanda remains undeterred and further manages to intercept a crew that was illegally smuggling some essential commodities out of the country. In the ensuing battle, he is injured, and hospitalized and later killed in hospital. Kamkanda loses his life due to his unrelenting efforts towards championing the rights of the workers and citizens of low socio-economic status. Mtobwa juxtaposes antagonists with heroic traits against the anti-hero protagonists. The anti-hero reigns and, for the most part carries the day. The author presents the society as one in which non-heroic traits and practices like corruption thrive while any efforts to counter such traits are nipped in the bud. The voice of reason does not go far before it is completely blocked. Meanwhile the protagonist who is anti-heroic thrives throughout most of the text. This is a feature of popular literature. Urban fictional works like John Kiriamiti's My life in Crime, My life with a Criminal; Major Mwangi's Going Down River Road, for instance, are some texts in which the anti-hero protagonists are prominently featured. In these (urban literature) texts, true heroism has little space of survival if any.

Mtobwa gives female characters in the texts sex-related traits. They are also reflected as helpless and having very limited options for survival in the socio- economically tough society. A number of female characters are presented as "sex objects." In Give me Money, Maua is a female character, a prostitute and a key accomplice to the corrupt, illegal deals of Kalulu, Bon and Kandili. Her name, "Maua" is a Swahili word for "flower". The name symbolizes physical beauty. She uses her body for personal material gain as well as for the benefit of the ill interests of her corrupt masters. Bon reveals to Kandili that Maua had deliberately been used to lay a trap for him. In further persuading Kandili to join them in their deals, Bon says, 'If all you want is Maua, I'll let you have her...' (16). The extent of Maua's sleaze is best displayed when she is sent by Idrisa Kalulu to convince the doctor to have Kamkanda (the union secretary-general) killed. She gives the poorly-paid medic a colossal sum of money and promises him her body. Mtobwa has been accused of misogynist depiction of rape scenes with the insinuation that the raped women (as presented in the case of Rukia in childhood) enjoy infliction of pain (Mabala 40). However, this study argues that Mtobwa uses Rukia to reflect the social environment in which the urban youth especially the females grow, their state of helplessness in the circumstances they find themselves in, the predispositions they are subjected to, and their limited options for survival in the urban settings. Etyang notes that urban poverty is not just a collection of characteristics but it is also a dynamic condition of vulnerability or susceptibility to risks (2). Rukia's presentation is also a case of resilience and determination in the midst of socio-economic adversity. She perfects the practice of prostitution especially after her mother's departure to Nairobi. Rukia is said to have been pushed into prostitution by her poor background. Circumstances had driven her into prostitution at a very young age. Rukia's mother was a prostitute. Mtobwa writes: Suppose she gave consideration to her age: what would she eat? For three days now her tummy had known no food. Her mother had again run away deserting her. And this time she (Rukia) had despaired... (3). Rukia ponders:

Now that her mother was no more with her, the time had come to advertise her experience and silence those who regarded her as a child. It was an absolute necessity if she was to make a living. The mere four years of primary education she had received would not get her anywhere. Had those with a better education found jobs? And even if she was to be lucky enough...how would the minimum wage help her when those in high income brackets were going to bed hungry? (4).

The environment can be said to have been at play, informing the trajectory taken by a majority of characters in the texts under study. Rukia is a typical case in point. In Mangua's Son of a Woman [9], Dodge Kiunyu, the main character, just like Rukia, was born of a prostitute mother, Theresa Ngendo. Kiunyu gets 
married to Tonia, also a prostitute who engages in commercial sex activities together with her mother. The prostitute motif is important in advancing the major thematic concerns in urban fiction. In Going Down River Road, Ocholla on being fired from his job seeks solace in a bar where he meets a prostitute with whom he starts living in the squalid residence similar to his.

Virtually all other characters have, somehow or other, been constructed around the phenomenon of post-colonial disillusionment. In Give me Money, mothers are said to live in poverty and a life full of tears especially as they helplessly watch their children die of starvation and curable diseases. This happens courtesy of the activities of economic saboteurs who have made essential commodities inaccessible to the common man. Dora is forced into prostitution as a result of frustration and disappointment in life. The rural folk in the villages suffer abject poverty. This is illustrated in the portrayal of the rural home of Hasira.

It is not only the poor who experience disillusionment. Women married to wealthy men, for instance, are presented as living a life of frustration. In Dar es-salaam by Night, for instance, Peterson's wife despite having material wealth is deprived of love from her husband. She perseveres with living with an unfaithful husband who shows her no love. Peterson's secretary, Grace tells her boss, "Excuse me sir...I forgot to inform you that your wife, Mama Sony, has been ringing for the past two days asking for you" (106). Peterson in response wonders, "What does she want?" He gives an excuse, "Tell her I'm on a business trip...Tell her some urgent business summon has taken me to Nairobi and that on my way back I'll call in Zanzibar" (107). Peterson is an absentee husband who delights in extra-marital relationship.

Another remarkable feature of Mtobwa's characterization in these texts is seen in the way he significantly attempts to invite the readers to see the world from the perspective of the youth and children. In Dar es-Salaam by Night, the early lives of Rukia, Hasara, Hasira and other youth are given considerable prominence in this text. Mtobwa realistically presents the youth and the hardships they undergo especially in their quest to improve their lives in the urban space. Children are not spared the socio-economic experiences and challenges facing their society. Mtobwa uses the device of flashback, in such a way that the reader can understand the background history of the characters. The characters are presented as self- aware of the largely misfortune-marred nuances of their formative years. Hasira and Hasara, for instance are cognizant of the inequities in their society. Hasira's early life revolves around the streets. His name means temper (or anger). He was the leader of a street gang. His life and that of his companions is described as one of dirty, poor children who lived on picking dumped left-over food from dustbins. He is used to depict disillusionment that characterizes street life and how extremely low socioeconomic circumstances drive certain individuals in criminal activities. Hasira like many members of the street gang are said to have moved away from his rural home in search of a better livelihood but he finds himself in the town streets. Faced with severe economic hardships, many citizens find themselves engaged in crime in order to survive. Hasira, for instance, rises from poverty to wealth by engaging in criminal and illegitimate activities. He at one point engages in a mission to have Peterson killed at all costs. Hasira in adulthood manages to acquire a considerable amount of wealth. He persuades his childhood friend Hasara to join him in his criminal activities if he wants to deliver himself from his life of misery. Hasira's life well exemplifies the relentless struggle and craving of the ordinary man to survive in the midst of the hardships of post-colonial urban life. The sociological approach to literature concerns itself with literature and its reflection of humans, their lives, activities and struggles in society. The sociological literary criticism investigates how mankind operates and persists in society. Mtobwa conveys a message to the effect that a considerable section of the urban underclass, particularly remains determined to survive in the urban space. There is also a sense of ambivalence on the part of the ordinary urban dweller over the state of affairs in the post-colonial urban society. As already noted, to some individuals, the metropolis offers a golden opportunity for socioeconomic prosperity and escape from rural poverty. Ikone Chidi et al.posits that the massive incursion of people into urban areas is as a result of sudden new tastes and wants which only the city can offer [20].

Hasara like Hasira spent his childhood on the streets. His name is a Swahili word for "loss" Mtobwa writes of Hasara, "He felt life had been unfair to him. How humiliating it had been to be so scantily dressed and sleep out in the open... Anger ruled his heart. He was full of indignation at the entire mankind' (42). The narrator goes on to say"

To him the world had been created good. God had intended people to be equal, but somewhere had gone wrong....He had heard it said so many times that the best anti-dote to inequalities was socialism. Yet even under socialism only a few seemed to benefit while the masses were condemned to suffering (133).

In Dar es-Salaam by Night Rukia who is abandoned by her mother at a tender age doesn't know her father either. Peterson does not know his mother and neither does Hasara know his parents. Rukia though a young girl becomes infatuated with Peterson, a relatively older man. The urban space and its complexities offer a break with traditional societal value systems. In a harsh life of survival-for-the- fittest in the metropolis where competition for financial freedom is stiff, individuals throw caution to the wind, 
in a quest to make it in life. The female gender is the most vulnerable in this situation. Rukia is therefore, desperately in need of one who would deliver her from her poverty and economically uplift her.

When she first saw him she had fallen for him after seeing the way he ordered beers: It was as if he had all the money in the world. And not only beer: he would order roast chicken now and again and generously tip the bar-maids. Rukia had thought a man like that would satisfy her lust for money (2).

Rukia's socio-economic life soon improves courtesy of Peterson and other men who pay her for sexual services. She owns a car and a big house.

Towards the end of the text, however, Peterson and Rukia discover that they are actually brother and sister born of the same mother but different fathers. Their love lives are shattered. Rukia's anticipated wedding to Hasira cannot proceed. Peterson is ashamed of his past relationship with Rukia. These three characters seem to mediate a situation of hopelessness, desperation and intense rot in the society-a situation in which there aren't the slightest traces of solution to the socio-economic conflicts afflicting the society.

\section{Disillusionment and Thematic Concerns in Give me Money and Dar es-Salaam by Night}

This sub-section looks at the interplay between disillusionment and thematic concerns addressed in the texts under study. The sub-section begins with a brief definition of "theme" as used in this study. Theme in Literature refers to the main ideas or underlying meanings in a literary text. A literary work may have major themes and minor themes (Souad 11-16). A major theme dominates and prevails in a text while minor themes are ideas that only appear occasionally in a text. Typically, writers express themes by means of exposing the thoughts and feelings of the characters especially the main character; utterances and conversations among characters; lessons learnt especially by the main character in the text; and the actions or events in the story and their possible implications.

Loomba (4) notes that post-colonialism, among other things, identifies social inequalities as an issue of concern in post-colonial societies. She further notes that post-colonialism aims to challenge the structural inequalities in society and bring about social justice. The inequalities result in myriad socioeconomic and political problems which the postcolonial African society continues to grapple with. Give me money and Dar es-Salaam by Night, like many postcolonial African urban novels present a nation whose ordinary citizens are in socio-economic woe. The themes addressed in these texts include rampant corruption in society, economic sabotage activities; class difference and socio-economic disparity between the poor and the rich; street life and crime, prostitution and moral decadence; oppression and exploitation of workers and ordinary citizens. The texts foreground such social ills as corrupt employment processes, insensate dispensation of justice by the arms of the state charged with the responsibility, deplorable social services, and imprudent use of sex for financial gain and sexual harassment.

\section{Rampant corruption and greed in society, and its psychological and social impact on the ordinary citizens}

One common theme of post-colonial texts from Africa is corruption by the ruling socio-economic elite. A notable case in point is Chinua Achebe's A Man of the People, a novel which satirizes and problematizes the re-shaped African society, casting a deep reflection on the emerging modern Africa with its multi-faceted challenges and experiences of growth and degeneration. The researcher of this study draws parallels between $A$ Man of the People and Mtobwa's texts in question. Corruption is at an alarming proportion in the societies represented in the texts in Give me Money and Dar esSalaam by Night. In Give me Money, the top management of the Oxton manufacturing factory are the main perpetrators of corruption. Led by Idrisa Kalulu this cartel of drug barons symbolizes the socioeconomic elite in the post-colonial society. This group practices brazen corruption. The elite work with relevant government agencies to execute their shady deals. By implicating the government in this state of affairs, Mtobwa problematizes the society's governance systems presenting the state not only as complicit in the vice of corruption, but also incompetent and insensitive to the plight of its citizens. The administrative and political class entirely comprising indigenous Africans is reflected as both socially and technically inept. Incompetence and lack of political will aids in the increase of corruption in society. It is only towards the end of the text after the ordinary citizen has suffered, after several deaths and after intense complaints and grumbling by the citizenry that the government purportedly swung into action. The crackdown by the government on corrupt cartels and economic saboteurs does not bear significant fruits either. Oxton is said to be a very rare medicine for curing the deadly disease Pallala. Toko is the only African factory producing this drug. Idrisa, the company's Managing Director however, capitalizes on this situation to export and hoard Oxton and thus deny the citizens this essential commodity.

Idrisa Kalulu, the infamous Managing Director of the Oxton factory finally bribes his way into politics. He is elected a Member of Parliament and appointed Minister of Human Rights. Corruption seems to have reached uncontrollable proportions in the society in question. This is a replica of what takes place in many post-colonial African states. Macheka, for 
instance, notes that almost everyone in independent African society is engrossed in corrupt practices. In his study of Chinua Achebe's A Man of the People, Macheka notes that Odili, who appears to be an antithesis of Nanga-and who, in fact, is critical of Chief Nanga is also hypocritical and corrupt (16). Odili in one instance of corruption uses C.P.C. money to cover his father's case of Tax Assessment Office and pays the bride price for his promised wife. Max, who is in agreement with Odili on the need to rid the country of corruption, also accepts money from the communist party and from Chief Koko. The extent of corruption in many post-colonial African states is such that the ordinary citizens are vulnerable and predisposed to an overbearing temptation to jump ship and join the corruption bandwagon. Ayi Kwei Arma's The Beautiful Ones are Not yet Born presents an indictment of the institutionalization and universalization of corruption and bribery in the Ghanaian society. Corruption is seen as the only means to socio-economic prosperity. In Dar es-Salaam by Night, Mtobwa in reference to Peterson writes:

He had seen some politicians preach equality during the day and pursue their acquisitive ends during the night.... He did not think the country's better than those of the countries he had been to... What kind of policies were these that closed people's eyes, made them clap with joy at some lofty ideal while the people who preached the ideal knew just what they wanted and got it? (75).

Peterson is conscious of the ills and inequalities in his society. Mtobwa writes that it had not taken Peterson long to realize that his education was not very useful in the society. Peterson had, in fact, begun to think that the time he had spent abroad studying was a waste of time (74). The narrator goes on:

He (Peterson) had come to realize that what mattered in the country was who you knew. It was a matter of "technical know who" and not "technical know-how". Knowing people who mattered and having them know you was more important than the paper qualifications (74).

Hasira and Hasara are constantly engaged in lament regarding the corrupt practices of government officials and the entire socio-economic elite. Hasara expresses a feeling of betrayal, frustration and disillusionment. Money and power seem to be revered in the society in question. The system supports the corrupt and the wealthy in society. The emergent African elitist class that had replaced Europeans is insensitive and completely at odds with the general ordinary population. Mtobwa presents a clear-cut conflict pitting the affluent in society on the one hand and the lowly on the other. The latter are a weaker voice-an oppressed lot of citizens who can only whine in hushed tones with no one to listen to their predicament.

\section{Poverty, class stratification, economic disparity and their impact on the urban society}

The themes of poverty, class difference, and economic disparity among citizens are also reflected in the texts under study. Myers takes a post-colonial perspective with regard to the socio-economic state of affairs in the African urban space. Myers notes that post- colonial cities have not made much progress in overcoming the colonial past. He notes for instance:

Changes to planning laws, building rules, the structures of the world economy, the national urban hierarchy, and political processes at urban and national levels, spatial divides and the character of racism are not going to occur overnight, if they are even possible. Still, if African cities have indeed been attempting to subvert or eliminate the colonial legacies over these post-colonial decades, one is fairly often hard-pressed to see the result (34).

In Give me Money, the theme of poverty is portrayed through several characters. The text presents a majority of the citizens as languishing in poverty, and children dying of diseases and hunger. The theme of poverty among citizens is related to disillusionment. The theme of class difference is also prominently featured in the two texts. Kehinde notes that one of the problems of post-colonial betrayal in African nations is the insatiable quest for wealth by the indigenous sociopolitical elite (235). For lack of opportunity to compete with the rich on a fair footing, the masses get increasingly poorer. This problem finds expression in the two texts under study. In Give me money there is a sharp socio-economic disparity between the likes of Idrisa, Bon, Kandili on the one hand, and Kamkanda, workers at Toko and majority citizens who wallow in poverty and disease on the other. There is socioeconomic class difference between the minority elite and the majority urban underclass.

The same scenario is presented in Dar esSalaam by Night in the extremely affluent life of Peterson on the one hand, and the street lives of Hasara and many other children and adults. The urban majority are frustrated by this state of affairs. The quest for wealth and other forms of material gain has divided the society. There is a wide dichotomy between the rich and the poor. The rich use all manner of corrupt means to amass wealth as the poor languish and sink deeper in poverty. The socio-economic elite are insensitive to the plight of the common man. This is to a great extent due to capitalism and consumerism-systems or practices which can be ascribed to the interaction between Africa and European colonialist. Bon Kolo convinces Kandili to believe that he doesn't have to mind about others, so 
long as he (Kandili) was gaining from the shady deals. As a result, the urban society remains largely one in which the majority remains confined if not consigned to a miserable life characterized by poverty, unemployment, squalid living and a general lack of basic social amenities. Dar es-Salaam by Night vividly captures the street life in urban Tanzania featuring Hasira, Hasara and their counterparts.

Children fought for food with stray dogs and cats. They fought amongst themselves too, something that sowed seeds of hatred and suspicion among them. Hasara... remembered how Hasira had one day broken him a slice of dry bread out of pity. The bread was nearing decay but it was at least something with which to allay the hunger in his stomach (9).

Argo comments that generally, postindependence Africa is faced with a horizontal rift separating the elite from the masses [1]. Kehinde further observes that the African society is engulfed in poverty (231). He notes that the wealth is in the hands of a privileged minority which surrounds itself with country houses, cars, washing machines, television sets and all the consumer durables associated with an acquisitive middle class (231).

\section{The causes of crime, incest, prostitution and moral decadence in the urban society}

Dar es-Salaam by Night vividly reflects the magnitude of prostitution and moral decadence in the night-clubs and hotels of the city of Dar es-Salaam. The text portrays a situation of moral degradation and disintegration. This situation can be traceable to the colonial period. It is a reflection of moral confusion and chaos. It is a society marred by breakdown of traditional moral values.

The prostitution motif is prevalent in many urban literary works. In Major Mwangi's Going Down River Road, Ben and Ocholla seek solace in alcohol and women in the midst of socio-economic hardship in the urban space. The society in question seems to relegate the female gender to the periphery. Women are "objectified", and only given inferior, subsidiary roles. In several instances they are also presented as evilminded. Idrisa and Bon in Give me Money use Maua to execute several atrocities. She is used as bait to "coerce" Kandili to join the corruption bandwagon of Idrisa and Bon. Maua is sent by Idrisa to entice the doctor with money and a promise of her body in order to have him administer a drug which eventually kills Kamkanda while undergoing treatment in hospital.

Kurtz traces the relegation of women in the post-colonial urban space to the period of European colonization of Africa. He notes that in the white colonial administration, Africans had been considered temporary residents in the cities. Men had not been allowed to bring their families into the cities. African women had been considered a menace whose role was to 'immoralize' the urban male and the urban space [18]. This study argues that this patriarchal stance by the colonial powers was significantly responsible for the experiences women and the female gender at large were undergoing in the post-colonial urban space in Africa. The notion of male domination and virtual feminine absence in the urban space was being perpetuated in the post-colonial era. Maua and Dora are presented as prostitutes. Maua is said to allow her body to be used as bait for financial gain. She like Rukia in Dar es-Salaam by Night is presented as a beautiful lady, a prostitute whose main expertise lies in offering sexual pleasure to many men.

Musangi underscores the significance of the bar in the post-colonial urban space. She notes that the bar is not only for the criminal but for most other urbanites whether in times of pleasure or adversity (68). Graebner notes that the bar is important to the urban dwellers not only for alcohol consumption but also because bars are the normal context of prostitution-the normal places where prostitutes and their male counterparts can meet and strike out their deals [18].

The perspective from which Mtobwa presents women can be said to be largely patriarchal. The society in question seems to expect women to look up to men as their superiors, and the only determinants of their livelihoods. They are expected to serve the whims of men. The presentation of women especially in urban literature texts exemplifies their position or state in society vis-a-vis their male counterparts. Dwivedi notes that the African society for the most part portrays women as weak, dependent, frivolous, and seductive (7). Hussein posits that the African society tends to cultivate "men's prerogatives to the allegiance and subservience of women to sustain the latter's subordination and marginality" (qtd. in Dwivedi 7). Etyang observes that there seems to be a sense in the African society in which women can be said to have been marginalized and that this has adversely affected their economic and political livelihoods (17). Peterson in Dar es-Salaam by Night engages in extra-marital affair with Rukia. Peterson has a negative perception of Grace, his secretary. In a generalization he wonders:

This was the fifth year Grace had been in his employment, but she had never despaired of trying to seduce him with her eyes and gait. What was wrong with women today... To them every man was a husband (51).... She would sit carelessly, her short dress notwithstanding and deliberately stayed behind when the day was over (52).

Women are also presented as victims of the harsh experiences of the post-colonial urban society. In Dar es-Salaam by Night, Mtobwa presents a unique 
dimension to prostitution and profanity in the urban society. This is mediated through the characters, Rukiaa prostitute-and two men, Peterson and Hasara. The level of disintegration of the family unit is such that cases of individuals in urban areas engaging in incest and other forms of sexual decadence are real. The high influx of people into the cities in search of a better livelihood is partly responsible for this kind of lifestyle. The pressures resulting from the harsh economic conditions in the metropolis, the insufficient employment opportunities, and runaway poverty that afflicts the general urban population predispose the urbanites to shambolic, disintegrated family lives.

Crime is also rife in the society presented in the texts under study. In Dar es-Salaam by Night street life is characterized by engagement in petty criminal activities. The kind of life the likes of Hasira and Hasara lead during their childhood is one that prepares and predisposes them to a life of crime and other dishonest practices. In adulthood, Hasara has made up his mind to use any possible means to escape his childhood, poverty-marred street life. He becomes a hard-core criminal engaging in a raft of criminal deals. The economically disadvantaged individuals find them vulnerable and left with very limited options for survival.

In Give me Money, Idrisa, Maua and the doctor collude to have a poisonous drug administered to Kamkanda for proving to be stubborn in advocating for the rights of the workers and the oppressed masses. Kamkanda passes on as a result. It appears natural in the oppressive capitalist post-colonial society to squelch by any means any forces that attempt to champion the cause of the masses. Hasara in Dar es-Salaam by Night and Kandili in Give me Money are used to communicate the prevalent notion in post-colonial Africa that the only means to socio-economic prosperity is through corruption and dishonesty. The economic elite live an extremely luxurious life at the expense of the entire country. This situation parallels not only the concerns of many post-colonial urban literatures, but also those of 'elite' literary works like Ngugi's Petals of Blood and Matigari. Both of the texts reflect corruption and capitalist exploitation of the poor innocent masses. Powerful businessmen, entrepreneurs and capitalist exploiters displace small-scale businessmen and deprive peasants of their lands (qtd. in Addei, Osei and Annin 166). According to Addei, Osei and Annin, in the capitalist ethos... human values are perverted and instead replaced with rampant exploitation and insatiable acquisition of wealth by the top few at the expense of the masses (166). In Ngugi's Matigari, the character Matigari toils but it is his boss Williams who reaps and enjoys the fruits of Matigari's labor (qtd. in Addei, Osei and Annin 166).
Kehinde notes that Major Mwangi in his popular literature works selects realistic details from ordinary life and chronicles the fate of an impotent silent majority. He further observes that life in the cities is full of pains and conflicts characterized by bad habitation, malnutrition, unemployment, distress, agony, starvation, cold, alienation, ill-health and misery (233).

\section{Oppression and exploitation of workers and ordinary citizens in the urban society}

The oppression and exploitation of workers and ordinary citizens as reflected in the texts under study is indicative of a society whose socio-economic elite have rendered hopeless and at the mercy of the same elite who are bent on driving them into slavish submission. In Give me money, the Oxton factory is used to epitomize the vice of victimization, oppression and exploitation of the ordinary workers. The workers at the factory toil but do not see the result of their hard work. The top management of the factory is preoccupied with the vice of trafficking and hoarding of the Oxton drug. Idrisa Kalulu is said to be cruel and inaccessible to his workers. To secure jobs at the factory, workers have had to bribe him. He uses many tactics to scare the workers and prevent them from airing their grievances. As already mentioned, Mtondolo, the chairman of the Oxton workers' union is promised a scholarship abroad when he goes to the Managing Director to present the concerns of the workers. He is instructed to take time off duty as he awaits the trip abroad. The union chair readily obliges. This is an illustration of betrayal of the ordinary citizens by one of their own. It is an act of selfishness by indigenous African leaders who on being entrusted leadership positions do not live up to the expectations of their fellow countrymen who entrust them the positions.

Kamkanda, the secretary of the workers' union puts up a spirited fight against the exploitation and mistreatment the workers are subjected to. Kamkanda is sacked by Idrisa, for having aired the views of the factory workers. Kamkanda is eventually killed for his adamant stance regarding the malpractices at the Oxton factory and other social ills in his society. Kamkanda's attempt at fighting for the rights of the ordinary man is crushed. The forces of the socio-economic status quo do not tolerate opposition or dissent. This presents a sad situation for the ordinary citizens who seem to remain helpless. The trade unionists' and the civil society's attempts at challenging the socio-economic elite are squelched with excessive brutality.

Vijay Mishra and Bob Hodge note that postcolonial criticism "foregrounds a politics of opposition and struggle, and problematizes the key relationship between centre and periphery (375-402). Urban Fiction addresses a sense of misadventure and unfulfilled expectations for the urbanites. The urban underclass is 
often at loggerheads with the capitalist elite class, who more often than not, stop at nothing to maximize on their exploitation and oppression of the poor. In the Oxton factory, workers kept on grumbling. They were working round the clock to produce the essential commodity, Oxton. But what was witnessed was an increased shortage of the very medicine, Oxton. Workers were fed up with continuing to toil to fill the bellies of a greedy few while their own children died of the epidemic (36).

Sexual exploitation is an angle of exploitation which pits women as the victims. McKeown notes that if urban literature presents cities as places where young men go to make their fortunes, they just as often depict them as sites of socio-economic opportunity for women (121). The texts under this study present a panoramic display of the urban space featuring female characters in a quest to succeed in the highly competitive city life. Give me Money and Dar es-Salaam by Night, just like many popular literature novels reflect the stark reality of young men and women who migrate into the urban areas to make their fortunes but end up disappointed, with women only seeking recourse in prostitution. In Give me Money, Maua is a classic victim of sexual exploitation. She purports to work with Ben Kolo, Idrisa Kalulu and Kandili Maulana, the masterminds of economic sabotage. Her role is to provide sexual pleasure to these men. Her sexuality is abused in many instances. Other than being used to lure the doctor into murdering Kamkanda, she has also been instrumental in bringing Kandili on board to the corruption syndicate spearheaded by Kalulu the Managing Director of Oxton factory.

This study cannot overemphasize the relationship between the phenomenon of post-colonial disillusionment and the other thematic concerns addressed in Give me Money and Dar es-Salaam by Night. Post-colonial urban literature reflects the intrigues and dynamics of post-colonial cities. The texts under this study aptly capture this state of affairs. The themes discussed in this chapter like rampant corruption and greed in society, and its psychological and social impact on the ordinary citizens; poverty, class difference, economic disparity and their impact on the urban society; the causes of crime, incest, prostitution and moral decadence in the urban society; and oppression and exploitation of workers and ordinary citizens in the urban society all have a bearing on the thematic concern of disillusionment. These thematic concerns have interrelated in a way that, from the focus of this thesis, effectively serves to foreground the fact of post-colonial disillusionment in post-colonial Tanzania.

\section{DISCUSSION}

How post-colonial disillusionment shapes ben mtobwa's authorial strategies and ideology

\section{INTRODUCTION}

This chapter focuses on the third objective of this study- the relationship between post-colonial disillusionment and Ben Mtobwa's authorial ideology. The theme of disillusionment, which dominates postcolonial (urban) literature, has a significant bearing on the literary artiste's ideological orientation. This is evident in a wide spectrum of texts written by postcolonial writers. These include the primary texts in this study-Give me Money and Dar es-Salaam by Night. This section, therefore, delves into ways in which Ben Mtobwa has, either consciously or unconsciously been influenced by the thematic concern of disillusionment in terms of his authorial strategies and ideology. The section begins with a brief definition of the concepts, 'ideology' and 'authorial ideology' from the context of this study.

\section{Ideology and Authorial Ideology}

The term ideology is widely used in the social sciences, in politics and in the mass media. There are, therefore, several definitions, versions and approaches to ideology. John Gerring remarks that it has become customary to begin any discussion of ideology with some observation concerning the term's semantic promiscuity (957). Gerring further notes that "few concepts in the social science lexicon have occasioned so much discussion, so much disagreement, as 'ideology",

The notion of ideology was first defined by French philosopher Destutt de Tracy at the end of the $18^{\text {th }}$ Century (Dijk 6). Dijk notes that for Destutt, ideology was nothing less than a general "science of ideas" (the study of "how we speak and argue"...), something akin to psychology or cognitive science. He goes on to provide a manifold definition of the term involving cognitive and social psychology, sociology and discourse analysis. He begins by defining the cognitive dimension of ideology in terms of social cognitions that are shared by members of a group. He defines the sociological dimension of ideology as concerned with explaining what kind of groups, relations between groups and institutions involved in the development and reproduction of ideologies. The discourse dimension of ideologies, according to Dijk, explains how ideologies influence our daily texts and talk, how we understand ideological discourse, and how discourse is involved in the reproduction of ideology in society (5). In the context of this study, ideology is used to mean the fundamental beliefs (and values) of a group of people (or individuals in a particular group). 
In literature, ideology may be defined in terms of a collection of values informing the content and form of a text (Raymond Williams 1-5). Authors may either overtly or covertly communicate their espousal of certain ideological standpoints in their texts. Literary criticism involves not only evaluating the worth or quality of a piece of literature but more importantly, explaining and attempting to reach a critical understanding of what literary texts mean in terms of their aesthetic, as well as social, political, and cultural statements and suggestions. Part of this great task involves seeking to reach a logical and reasonable understanding of what emerges (either explicitly or implicitly) of an author's intentions, beliefs and viewpoints. Literary artists generally construct their work around particular ideologies, which they adopt or develop both consciously and unconsciously. Marxism is one of the major ideological orientations adopted by writers in literature.

Marxism finds prominent expression in literary circles. It comprises a set of social, economic and political ideas that are believed (within the ambit of the ideology or theory) to entail the blueprint for interpreting and changing the world (Williams 1-5). Marxism is premised on the intention and hope to create some kind of equilibrium that makes the world a better, more secure place (especially) for the oppressed in society. A writer inclined to this ideological thought will construct his text around the thematic concerns of exploitation and oppression of workers, class struggles, rebellion and the need for revolution as a means to emancipation among others. A number of writers have been found to be inclined to this particular ideology. Robson, for instance, rightly argues that Ngugi is a revolutionary writer who has used both fiction and nonfiction to reflect the problems of underdevelopment, class exploitation and state repression (1-18). A writer's ideology is informed by a variety of factors, which include real life experiences. Fraser ascribes Ngugi's ideological standpoint to the author's entire life, beginning with his early life in Kamirithu village. Ngugi's rural village met the wrath of the "Mau Mau" independence movement wars. Ngugi's later life from the pre-colonial to the immediate post-colonial era further contributed in shaping his Marxist tendencies. This as noted by Fraser is evident in the trajectory of his post-colonial literary works. The socio-political events in Ngugi's society and their attendant experiences to a great extent contributed to his adoption of Marxism and the Marxist literary theory. In the same vein, this study found an interplay between the thematic concerns of the post-colonial Tanzanian society as addressed in the texts and Mtobwa's authorial strategies and ideology.

Ben Rashid Mtobwa was born on $28^{\text {th }}$ August 1958 at Kigoma in Western Tanzania. This was a time of heightened agitation for independence by many African countries which were under European colonization. At the time of writing and publication of his works, many African countries, and indeed, all the three East African countries-Kenya, Uganda and Tanzania- had attained independence and were reeling from post-colonial experiences including neocolonialism. Mtobwa, therefore, experienced first-hand the immediate social problems and challenges facing the Tanzanian urban society in the post-colonial period. Macheka observes that a number of post-colonial writers subscribe to the notion that independence is a source of disillusionment to most black Africans because it has failed to deliver on the key objectives that spurred the quest for independence(14). Macheka further observes:

The sad aspect of current African politics is that colonial encounter is blamed entirely for poor governance, yet the blame mostly lies on endogenous factors behind that such as corruption, nepotism, manipulation of media, mass apathy, politics of lies, demonization of democratic values, politics of deception and self-aggrandizement, ethnicization of politics and naturalization of election violence. In a sense, it is not a fulfillment of expectations but a nightmare, an illusion that created a false sense of arrival (14-15).

Fage and Roland assert that the independent African post-colonial elite "championed the first movement of African nationalism, coerced its political demands in terms drawn from European nationalists' thought" [21]. This in essence means that independence for Africa in the strict sense of the word was not achieved. As such, the African person remains yearning for independence. The victory that Africans thought they were welcoming in its fullness has remained elusive todate. For the most part, as Macheka observes, what actually happened at Africa's independence is that, black oppressors replaced colonialists and there was mere substitution. It is the social concerns emanating from these problems that were to bear upon Mtobwa's authorial strategies and tendencies.

\section{Ben Mtobwa's authorial ideology}

Having discussed the concepts of 'ideology' and 'authorial ideology', this section investigates Ben Mtobwa's authorial ideology as manifested in his two novels-Give me Money and Dar es-Salaam by Night. As already mentioned, African post-colonial literary artistes endeavor to reflect a wide array of thematic concerns that mainly emanate from the experiences of European colonization of the continent. The sorry experiences and immediate social concerns of the urban underclass, particularly, find clearer and more elaborate expression in urban fiction. Urban literature for the most part, thematically consists in disillusionment. It is this study's contention that, in terms of ideology, the post-colonial (urban) writer is significantly influenced by the ubiquitous tone of urban disillusionment. The two primary texts under study, as discussed in the latter 
part of this section, significantly illustrate the extent of the influence of disillusionment on Mtobwa's authorial strategies and ideology.

Kehinde [2] notes that in the post-colonial period, African writers have become more realistic than ever before. He observes, for instance, that African writers now examine more critically how their people have been governing themselves and what they have made of their independence. This critique of one's society is, crucial if not responsible for the formation of the African writer's authorial consciousness.

A close examination of Mtobwa's texts reveals his propensity towards popular literature. Maina posits that popular literature is a mirror of society for people who want "people of their kind"portrayed in literature [22]. This assertion can be construed to mean that, in comparison with the 'elite' literature, popular literature more prominently reflects (the concerns of) the lowly in society through characterization. It is worth noting that this category of citizens represents the majority of the population in the African society. In view of this, it can be argued that African Popular literature significantly depicts the general socio-political state of affairs in the continent. The general situation in the post-colonial African states is one in which the ordinary citizens, who are given prominence in popular fiction, for the most part, have been impoverished by their fellow Africans' regimes. This is a major cause of disillusionment in post-colonial African popular fiction. Wanjala notes that the reader of popular literature (in this case the nonelite, the ordinary citizen or the average reader) "looks for an artificial paradise which this literature offers and they use it to escape the reality and hell in which they live" (69). Barber remarks that popular literature emanates and pertains to the people, appeals to the common people... "is simple...is easy-reading, presenting itself in easily-digestible, entertaining form and confirming prejudices rather than challenging them" [22]. The Popular literature sub-genre comprises thrillers and suspense fiction, crime and detective novels, romance fiction, mystery fiction, and horror fiction, among others (4-7). Thriller or Suspense Fiction is usually associated with their ability and tendency to elicit in the reader (or audience) moods like suspense, excitement, surprise, anticipation and anxiety.

It usually involves incidents like "ransom, captivities, heists, revenge, kidnappings, investigations, violence, crime and murder" [23]. Mystery Fiction basically involves (mysterious) death; a crime to be solved; and the supernatural, among others. Science Fiction involves imaginative concepts like futuristic science and technology; space travel; time travel; fasterthan-light travel; and extraterrestrial life. Horror fiction has the capacity to frighten, scare, disgust, or startle the reader. It also involves the supernatural. Thrillers, on the other hand, are full of adventurous episodes.
According to Wanjala, "to be asked to address any gathering on popular literature means being asked to address it on literature in which characters are trade unionists, workers, students, prostitutes, and street children" (61). This is evident in Ben Mtobwa's works right from the earlier ones which included the widely acclaimed detective series featuring Joram Kiango. Gromov notes that "Mtobwa made a pioneering effort of using a detective story as a vehicle of serious social criticism turning popular literature into an instrument to increase the social awareness of his readers"(321-325). An urban fiction writer in post-colonial era, Mtobwa's pre-occupation with the social ills in the society and the predicament of the ordinary citizen smacks of the impact of these experiences on his consciousness. Mtobwa himself in an interview with Mikhail Gromov alludes that he held deep convictions of the need for his society to be emancipated from the social malpractices that bedeviled it (150-155). He believed he could use literature to crystallize the sorry state of the Tanzanian society in order to put the common man in a position to understand the intricacies and magnitude of social sleaze in the country. In reference to his production of many detective works, Mtobwa intimates that it was his strategy to first endear himself to the Tanzanian readership especially the youth who lacked a reading culture. His detective works, therefore, resonated quite well with majority of the Tanzanian youth population. It is the youth category that forms the majority of the disenchanted urban underclass.

Mtobwa used the detective sub-genre to appeal to his readership and win over them by entertaining them while at the same time enlightening, reminding and revealing to them the social roots of crime and corruption in their society. He reckons that although his initial works in the detective series were being informed by the Cold War in the West, he later focused his detective novels on the deteriorating socio-economic situation in Tanzania [17]. Mtobwa further states that he had to initially stick to the detective novel since it was a sub-genre he could safely use to indirectly point out social ills without attracting the wrath of socioeconomic and political barons in his country as had been the case with the likes of Ngugi wa Thiong'o in Kenya or Chinua Achebe and Wole Soyinka in Nigeria [17]. Mtobwa's detective novels comprise the series of adventure novels featuring Kiango. The series includes: Lazima ufe Jorum [24]; Dimbwi la Damu [14]; Tutarudi na Roho Zetu (We will return with our Souls, 1984published in English as 'Zero hour'); Najisikia kuua tena (I feel like killing again, 1985); Jorum Kiango mikononi mwa Nunda [9]; Salamu toka Kuzimu (Greetings from the underworld,1987); Malaika wa Shetani (Angels of satan,1988); Nyuma ya Mapazia (Behind the curtains, 1996); Roho ya paka (Soul of the cat, 1996); and Mtambo wa Mauti (Device of death, 2004). 
According to Gromov, some of Mtobwa's thematic concerns include engagement in criminal activities especially by the youth, rampant corruption involving government officials, poverty and the wide disparities between the rich and the poor, sexual exploitation of women and young ladies, unemployment, exploitation and oppression of the ordinary citizens in places of work (323-324). All these are issues that largely revolve around disillusionment.

In Give me Money and Dar es- Salaam by Night, Mtobwa is intent on pointing out the immediate socio-economic and political malpractices in his society. Mtobwa presents many characters both as children and youth growing up in socio-economic hardship, and as adults who have no option but to continue grappling with the increasing challenges of urban life. In both texts, children and the youth are prominently featured. In Give me Money, for instance, Mtobwa elaborately presents the early life of Kandili Maulana, the main character. The situation of Kandili's siblings and other children is also vividly depicted in the text. Mtobwa takes the reader through the life of Kandili from his school-going years through his youth until the time that he becomes a fully grown-up adult. His entire childhood and youth life is marred by experiences which cause disillusionment. Up to this point, Mtobwa uses Kandili to mediate the abovementioned sorry state of affairs for the ordinary people in post-colonial Tanzania and Africa at large. Mtobwa further uses Kandili to depict how the society's corrupt elite gradually recruits more ordinary citizens into their corruption bandwagon, rendering the rest of the society increasingly vulnerable. Mtobwa presents the theme of betrayal. He reflects ways in which more individuals join the corruption bandwagon further compounding situations for the remaining majority urban underclass. In Dar es-Salaam by Night the early lives of Hasira and Hasara are highlighted. They are said to have spent their childhood on the urban streets of Tanzania. As a result, Hasira in his late youth and adulthood resorts to criminal life. Both youth are disillusioned as manifested in their actions, thoughts and conversations which are often laced with complaints and lament. The early lives of Rukia and Peterson are also highlighted.

Other than the youth, Mtobwa also concerns himself with the demographics of women and the female gender. He presents the plight of the female gender in society in the midst of socio-political and economic inequities in the society. He reflects the gender relations in the society in question, painting the patriarchal view on women which exacerbates socioeconomic conditions for the female gender. In Give me Money, the likes of Maua are used as sex objects by the economically empowered Idrisa and Bon. In Dar esSalaam by Night, Rukia, the main character is a prostitute. Her mother too is a prostitute and so are many other ladies in the text. Mtobwa does not entirely present women as weak. Rather, he looks at the female gender as victims of circumstances-victims of gender inequalities in a male-dominated society. Kandili's mother is a mother who heads a family of many children. She is widowed and somehow managing to raise her many children. She's barely capable of fending for Kandili and his siblings in the harsh socioeconomic condition.

Mtobwa also concerns himself with the family, the basic unit in society, its disintegration or break- up and the attendant repercussions in the urban setting. In Dar es-Salaam by Night, Rukia's mother, a commercial sex worker abandons Rukia at a tender age. Rukia is left with no option but to engage in the same vice that her mother and her immediate social environment predisposed her to. She perfects her skills in commercial sex work. Hasara has no idea about his family background. He had found himself living on the streets. He is born of the same woman who gave birth to Rukia. He was apparently neglected by his mother and he ended up on the streets. Peterson, a highly affluent man is perturbed by the fact that he does not know his mother. The trio of Rukia, Peterson and Hasara despite being born of the same mother do not know their roots. They have grown up in the city, where apparently, family values and stability have degenerated. Mtobwa reflects the reality and repercussions of family break up in the urban settings. The relationship between Rukia, Peterson and Hasara is a case of incest. At some point Hasara and Peterson almost fight over Mtobwa Rukia. It is apparent that Mtobwa does not merely engage in a mechanistic reflection of reality...rather he portrays the reality and at the same time attempts to persuade the reader to form an attitude.

Mtobwa engages in a blatant exposure of the extent of corruption and immorality in his society. In Give me Money, Mtobwa reconstructs a situation of things having fallen apart in the once-tranquil Tanzania in the period following Uganda's invasion and the ensuing retaliation by Tanzania. Lindemann and Putzel pinpoint Tanzanian war with Uganda as among key factors that exacerbated the socio-economic and political situation in Tanzania. They note that during the war, the country diverted its attention from important issues even as certain individuals took advantage of the lapse that was created (20-22). They further note that the size of the campaign for the war and the impact it had on the armed forces generated more problems. Lindemann and [26 Putzel state:

As Tanzanian forces returned victorious there were no immediate efforts to downsize the army, which had grown enormously due to the war effort. The military was virtually given a free reign to establish these units at home with little regard to the costs this would incur on the state budget or the economy, particularly given the context of economic crisis in the country. Militias, expanded for the war effort, got 
involved with robbery and other criminal activities (22).

Mtobwa uses characters like Idrisa Kalulu, Bon Kolo and Kandili Maulana as a metaphor for the crop of economic saboteurs who emerged in the country and further contributed to further plunging it into serious economic crisis. Mtobwa uses the text not only to highlight the situation but also to castigate the elite and express his abhorrence of the betrayal of his nation by a clique of corrupt economic elite.

\section{Disillusionment and Mtobwa's Authorial Ideology in shaping artistic strategies in Give me Money and Dar es-Salaam by Night}

This sub-section specifically delves into the phenomenon of postcolonial disillusionment and its relationship with Mtobwa's authorial ideology and his choice and use of the artistic strategies in the texts under study. Lindemann and Putzel note that postcolonial Tanzania is an "enduring oasis of peace" in the Eastern African region otherwise characterized by instability and violence (1). They further note that Tanzania is an amazing case of state survival as well as a society and polity which have enjoyed relative peace since independence. However, this study found out that the Republic of Tanzania too has had a fair deal of socio-political and economic challenges-a situation which has had adverse ramifications on the entire postcolonial Tanzanian society. Therefore, as already alluded in the sections above, Tanzania, like many postcolonial African states, has remained one in which majority of the citizens, especially the urban underclass, are largely disillusioned. Addei, Osei and Annin note that "after African countries gained their independence from their colonial masters, one would have expected a happy life in African societies but this is not so (167).

To the ordinary Tanzanians, life in the postindependence Tanzanian society has never been an easy one, after all. A few years into the country's independence, Tanzania's political stability had started getting increasingly shaken. The peasants, workers and civil servants were facing frustration and disappointment as a result of the post-colonial government's apparent failure to meet their immediate independence expectations and demands. The mid1960s witnessed an increasingly growing divide between the government on the one hand, and the social base comprising the nationalist movement, poor peasants and workers on the other. Desperation and frustration were beginning to develop among the latter category. Even with the Arusha Declaration (1967), made to address these challenges, things did not seem to improve for the ordinary citizen. The implementation of the Arusha Declaration in itself, for instance, posed a major challenge, with more socio-economic challenges emerging.
Ben Mtobwa's texts, Give me Money and Dar es-Salaam by Night are set during a period of heightened socio-economic crisis in the republic of Tanzania. The late 1970 s and early 1980 s was a period of growing desperation among the ordinary Tanzanian citizens. The situation around this time in the Republic of Tanzania greatly shaped Mtobwa's authorial ideology and strategies as manifested in the texts under study.

Mtobwa's preoccupation in the texts under study, therefore, revolves around the socio-economic and political challenges facing the Tanzanian society in the period up to around the 1980s. Mtobwa seeks to draw the attention of the public to the social ills and malpractices in post-colonial Tanzania. In Give me Money, Mtobwa decides to realistically reconstruct and portray the major historical happenings and events in post-colonial Tanzania. As is the case with the urban fiction sub-genre, the text features a wide range of characters including the peasants, workers, street persons, prostitutes, criminals, government institutions and officers, political leaders as well as the business class. Mtobwa prominently dwells on the actual happenings in post-colonial Tanzania. These include the challenges that occasioned the making of the Arusha Declaration or Ujamaa policies; the ensuing disappointing developments arising from the government's failure to effectively implement the policies; the war with Uganda and its aftermath; the emergence of economic sabotage and its effects, and the government's belated and unfruitful crackdown on economic saboteurs. Mtobwa, for instance, writes:

Kamkanda's bitterness was not surprising. Nor was it pretended...He had every reason to sorrow for his country...from the day he had arrived back in his home village from the war in

Uganda and found everything contrary to his expectations...He was the only survivor in the family, heartbroken and wretched (39).

In Mtobwa's view, the emergence of selfish economic saboteurs in the 1970s and early 1980s caused the greatest direct socio-economic and political blow to the republic of Tanzania. Mtobwa sees a situation in which a syndicate of corrupt economic saboteurs is economically enslaving the ordinary citizens with abandon. Mtobwa seems to launch a condemnation of the ruthless exploitation and oppression of the masses by the corrupt in society and those in privileged positions in general. Give me Money particularly prominently reflects this situation. To Mtobwa, the government too does not exhibit the true will to salvage its ordinary citizens who suffer in the hands of the socio-economic elite. Mtobwa explicitly presents his abhorrence of the social malpractices and inequalities in the Tanzanian society. He juxtaposes a minority group of the socio-economically privileged in 
society against the majority ordinary citizens who are by any accounts victimized, oppressed and impoverished. In both texts, majority of the citizens are socio-economically held hostage by the elite in society. In Give me money, the beginning presents the main character, Kandili Maulana as not only disappointed at the trajectory of events in his life, but also enraged-to the point of being ready to commit murder. The text begins thus:

The cold air that usually comes with the month of October in Arusha was wafted by a slight breeze on to the skin of Kandili Maulana, making him feel as if he had come into contact with water just out of a fridge....He was hiding in a bush, a sharp sword at the ready in his hand. He was quite determined to finish off the task for which he had set out. He intended to kill... "I have to do it," he swore under his breath (1).

In Dar es-Salaam by Night, Hasira is seen persuading Hasara to join in the scheme to have the wealthy man Peterson executed (33-34).

Life in the urban setting is also juxtaposed against the rural setting. Situations are very pathetic in the rural areas where the dwellers can only bank their hopes on their relatives who have left for the urban areas. There is a general sense of apathy in the rural. On the other hand, individuals who have migrated to towns encounter a new set of challenges. The urban immigrants are, however, hard pressed to return to their rural areas despite the frustration and disappointment they face in town. They cannot withstand the disappointment of their aged, ailing and school-going kinsmen and kinswomen who bank on them for socioeconomic salvation.

Mtobwa is critical of practices introduced from the West like capitalism and consumerism. He sees capitalism as a major contributor to the exclusion and alienation that majority of citizens in urban Tanzania continue to suffer. The author seems to suggest that the ordinary citizens, despite their numerical strength appear helpless and faced with very limited options for socio-economic and political emancipation. Mtobwa lays bare a society in which the ordinary people are powerless and stripped of their right to their country's economic and material resources. Success in life seems to be entirely predicated on socio-economic and political expediency. The conventional traditional value systems of the society including the ideals of Ujamaa are pushed to the back burner, and instead, the society seems to glorify the selfish practices associated with capitalism. Bon Kolo in Give me money remarks that it's mental bankruptcy to think of others instead of using whatever available means to get oneself out of poverty (23). Kolo in another instance remarks that a good hero is one who makes himself a pile of money
(45). When Kandili finally joins Bon Kolo and Idrisa Kalulu, the main agents of corruption in the text, it is remarked that he was now somebody. His name is said to have started resounding in both the town and the surrounding villages. In Dar es-Salaam by Night, Peterson is described as extremely affluent and extravagant. He has amassed huge wealth (17). Hasara is said to be wary of the fact that while children in many families were living in extreme poverty, there were rich people who juggled money like poker-cards and had more than they could spend (13).

Mtobwa wishes for a society in which there is social justice and equity among all the members of the Tanzanian society. He satirizes the socio-economic and political elite of the society in question. In Give me Money, Idrisa Kalulu, the Oxton factory boss who is by all standards a senior economic saboteur in the society in question later enters the world of politics becoming not only a Member of Parliament, but also Minister of Human Rights. Mtobwa writes:

It was a laugh to hear Kalulu promising to do all in his power to ensure that socialism was ushered into the country to bring equality to all. He was so convincing he could sway the crowds and move them to tears. But Kalulu could not fool a man who knew him as well as Kandili did (71).

Mtobwa employs symbolism in his texts. His choice of night life in urban Tanzania may in itself be seen as symbolic. In Give me Money, for instance, Mtobwa presents an embittered Kandili Maulana right at the beginning of the text ready to commit an atrocity in the darkness of night time. This deliberate choice of night life points to the author's intent to reflect the life of doom and disillusionment that the ordinary citizens in post-colonial Tanzania were being subjected to. Kandili is braving the night darkness ready to avenge himself on Bon Kolo, a key agent of corruption in society. The title, 'Dar es-Salaam by Night' in itself points to the author's deliberate choice of night time. In this text, the author has chosen to explicitly describe night life in Dar es-Salaam city. The city is described as awash with activity, most of which revolve around black marketeering, economic sabotage, prostitution, trickery and crime.

The author presents a picture of situations in the work sector noting that, in the society in question, jobs were hard to come by especially for the ordinary citizens who did not have relatives or god-fathers. A few who were lucky to secure jobs on merit were subjected to all manner of mistreatment. The situation is no different from the deplorable state of factory workers and inhuman attitudes of employers towards their employees that Ngugi reflects in Matigari... "the factory building itself was inside a wall of metal sheeting, while barbed wire fenced the workers' 
quarters like prison...the guard sat on a stool...” (qtd. in Addei, Osei and Annin (168).

In Give me Money Mtobwa describes Kalulu, the Managing Director of the Oxton factory as a cruel man notorious for sacking workers for mere trifles; a man who would not be moved to pity even by the shedding of tears (20). "It was well-known that people were employed after giving a 'dash' to Kalulu” (20).

Mtobwa seems to take the view that the characters in the post-colonial Tanzanian society are products of the same society in which they live. In Dar es-Salaam by night, for instance, Rukia, after being neglected by her prostitute mother is faced with very limited options. She can only resort to what she has observed or learnt from her mother. She gets into prostitution at a tender age inorder to fend for herself. Hasara, born of a prostitute woman finds himself in the streets with other street children. Hasira migrates from his rural home to seek a better livelihood in town but ends up in the town streets. He hardens up in the harsh street life where the means of livelihood generally borders on criminal activities. Many of the characters are presented as victims of the circumstances over which they have no control. Most of the characters, it appears, have some justification to live the kind of lives they have personally resorted to. The author in several cases uses the actual names of places and individuals he is narrating about. For instance, he mentions "the forces of the fascist Idi Amin of Uganda" and the rural area of "Mtukula" which was one of the battle grounds in the war (39). The urban centres like Arusha, Mwanza and Dar es-salaam too are not imaginary but are actually existing towns in the republic of Tanzania. Since his primary readership is the Tanzanian society, his use of familiar names further serves to crystallize the real state of affairs that Mtobwa sets out to castigate. Dar esSalaam by Night presents a vivid description of the kind of activities that take place in the real Tanzanian city of Dar es-Salaam. Mtobwa also uses flashbacks a lot in the two texts studied. Addei, Osei and Annin note that the use of flashback may demonstrate the significance of the interpretation of the past and the present (171). It can thus be construed that in Mtobwa's view, the present is best interrogated against the backdrop of the past. In particular, the socio-political and economic experiences that Mtobwa addresses himself to in the two texts under study, have been borne upon by previous experiences. This also resonates with the above assertion that prior experiences of individuals predispose them to the kind of characters and dispositions they adopt or acquire later in life. It is in the same vein that Asma remarks of the post-colonial theory: that the culture and society of the colonized countries before colonization help us to understand more the colonial mechanisms and the new culture and society of the post-colony (19).
There is also a sense in which Mtobwa expresses concern over the issue of betrayal in postcolonial Tanzania. Kandili's about-turn (when he joins Kolo and Kalulu), for instance, can be seen as an instance of betrayal of the ordinary citizens by their fellow countrymen. The citizens do not suffer under the hands of strangers but their very people who have been acculturated into corruption. The behavior of the Oxton workers union chairperson also presents a case of betrayal.

Mtobwa presents a situation of shattered dreams among several characters in the two texts under study. Give me Money, for instance, ends on a hazy note as to the success of the belated government's crackdown on economic saboteurs who continued to exploit and impoverish the country. The text's ending presents a tone of cynicism, apathy and despondency among the ordinary citizens. In Dar es-Salaam by Night the realization by Rukia, Peterson and Hasara that they are actually born of the same mother and must, therefore, end the sexual relationship is a case of disappointment and shattered dream.

Mtobwa exposes the malpractices related to gender inequality in his society. In a disillusioned society marred by poverty, corruption and all manner of social malpractices, the most vulnerable in societyfemales and children bear the brunt of the effects. The society in question is largely patriarchal. Mtobwa presents a female gender that is virtually voiceless in society. Maua and Dora in Give me money and Rukia, the main character in Dar es-Salaam by Night, for instance, are cast as sex objects. Bon Kolo in Give me Money and Peterson in Dar es-Salaam by Night are described as promiscuous wealthy men. To Peterson, sex outside marriage, for instance, had become a habit (17).

Mtobwa does not seem to suggest to his readers the remedy to the problems afflicting the society. Rather he simply presents to them a clear picture so that they themselves would be able to evaluate the happenings on their own. The author too does not seem to paint a picture of hope to the members of the society in question. There is a sense of suspense and lack of clarity as to the trajectory of the state of affairs in the said society, going by the endings of both texts. Mtobwa's conclusion of the texts under study is also a pointer to the author's view that there still lie difficulties ahead with regard to restoring socioeconomic sanity for the ordinary people in the society in question.

This section, therefore, underscores the existence of a strong interplay between the phenomenon of disillusionment in post-colonial (urban) Tanzania and Mtobwa's authorial ideology as well as his choice of the artistic strategies in Give me Money and Dar esSalaam by Night. As explicated above, Mtobwa 
witnessed and in fact felt the experiences of postindependence (urban) Tanzania which were largely informed by colonialism and its aftermath. These experiences, for the most part, resulted in disillusionment of the ordinary Tanzanian citizens and greatly shaped Mtobwa's authorial consciousness and his adoption of the artistic strategies employed (by him) in the two texts studied.

\section{SUMMARY, CONCLUSIONS AND RECOMMENDATIONS}

This study set out to investigate the theme of disillusionment as depicted in the post-colonial urban fiction of Ben Mtobwa: Give me Money [13] and Dar es-Salaam by Night [7]. The study argued that disillusionment pervades most works of post-colonial urban fiction and has a direct bearing not only on the structure and form of the texts, but also on the actual societies from which the texts are created. The study involved an in-depth critical evaluation of the relationship between disillusionment and socioeconomic, political and psychological factors in postcolonial African states, especially Tanzania. The study further analysed ways in which the theme of disillusionment shaped the two urban novels in terms of setting, characterization, and other thematic concerns addressed in the texts. The interplay between postcolonial disillusionment and authorial ideology and tendencies as well as artistic strategies was also evaluated in this study.

The study has argued that African urban fiction particularly consists in the theme of disillusionment. This is a reflection of the real Postcolonial African society in which the lives of the urban underclass are marred by disappointment, frustration, despair and disillusionment. It was further noted that the theme of post-colonial disillusionment significantly informs the writers' choice of the urban setting, the formation of characters in urban fiction as well as the thematic concerns in the texts. The study also noted that different African writers have overtime developed various authorial ideologies, tendencies and literary strategies which, for the most part, are greatly informed by (the impact of) post-colonial experiences (on their societies and the individual writers). The post-colonial experiences in Africa have mostly resulted in disillusionment of the ordinary citizen. On Tanzanian Society and Popular Fiction, the study noted that apart from classification into short stories, novelettes and novels, Tanzanian fiction has also been categorized into Popular Fiction and Elite Literature. Popular Fiction in Post-colonial Tanzania has been largely didactic and educational often pitting the good against the evil. The good in this context has referred to allegiance to the already set social value systems in the society. The evil, on the other hand, refers to transgressions against the traditionally set values.
The study argued that disillusionment as reflected in the two texts is occasioned by the real-life socio-economic, political and psychological experiences in postcolonial Tanzania at the period of the texts' production. It was discovered that postcolonialism in Africa, has its genesis in European colonization of the continent. The socio-political and economic factors which have contributed to disillusionment include betrayal of the ordinary citizen by a privileged, small group of political and economic elite; the exploitation and oppression of workers, impoverishment and dehumanization of the ordinary citizens especially the urban underclass by the elite. Capitalism, consumerism and other forms of selfish practices too disadvantage the common man in the society. The governance systems are rife with mediocrity, favoritism, bribery and other forms of corrupt practices. The extent of crime and immorality in the society is great. As a result, the ordinary citizens in post-colonial Tanzania and most of Africa are a disillusioned lot.

The study further argued that there is a twoway relationship between disillusionment and the socioeconomic, political and psychological experiences of post-colonialism. In this regard, the post-colonial experiences cause disillusionment among the citizens who, in turn, react in various ways further shaping their society socially, economically, politically and psychologically. In the same vein, disillusionment in the texts, as portrayed by the characters, results from the socio-economic and political factors surrounding the lives of these characters.

The texts Give me Money and Dar es-Salaam by Night vividly depict the interplay that exists between the social and economic factors in Tanzania in the wake of its independence, on the one hand, and disillusionment on the other. The theme of disillusionment to a significant extent influences setting, characterization and other thematic concerns in urban fiction particularly the texts studied-Give me Money and Dar es-Salaam by Night. The analysis noted that African urban life, and therefore, the urban setting comprises an array of social and psychological challenges which greatly affect the people living in urban areas. The study discerns interplay between disillusionment as reflected in the texts on the one hand and the texts' setting, characterization and thematic concerns on the other.

In terms of characterization, the study found out that many characters in post-colonial urban fiction are constructed in such a manner that they collectively help in advancing the thematic concerns of African urban life, which include disillusionment of the ordinary urbanites. As such, the study argued that there was interplay between disillusionment and characterization in the two texts studied. With regard to thematic concerns, the study argued that most of the 
thematic issues addressed in post-colonial urban fiction in Africa, especially in Give me Money and Dar esSalaam by Night have a close relationship with the theme of disillusionment. Themes such as corruption and economic sabotage activities by a small elite; exploitation and oppression of workers and the ordinary citizens; poverty and socio-economic stratification, crime, prostitution and moral decadence, and alienation of the common man pervade the two texts and other post-colonial urban texts and are interrelated with the theme of disillusionment.

The study also found out that the sociopolitical environment in which Mtobwa was born and bred (The African republic of Tanzania) was instrumental in the formation of his authorial tendencies and ideologies. To this extent, the phenomenon of disillusionment of the ordinary Tanzanian (urban) citizens has greatly informed the author's choice of the artistic strategies that he has adopted and used in the two texts studied. Mtobwa's texts point out a wide range of socio-economic and political malpractices in society particularly the Tanzanian state. The author highlights and castigates the acts of betrayal, exploitation, oppression and alienation of the citizens of Tanzania by a clique of socio-economic and political elite. He exposes the corrupt malpractices of top government officials and business barons who engage in a myriad of illegal deals like drug trafficking, hoarding of essential commodities and murder of innocent people.

Give me Money artistically recounts in great detail the corrupt deals in the Tanzanian society from the late 1970s. Dar es-Salaam by Night on the other hand is a love story which significantly deviates from the traditional Tanzanian love stories ending on the sad disheartening news for Rukia, Peterson, and Hasara who had been embroiled in a love triangle when they eventually learn that they are actually blood relations, born of the same mother. By this Mtobwa presents the situation of family break-up in the urban society and the resultant moral problems.

The study was delimited to the theme of disillusionment in post-colonial urban fiction of Ben Mtobwa-Give me Money and Dar es-Salaam by Night. A few secondary sources of data were used in the study which had a time frame of less than one and a half years. It is important to note that, a lot more research study needs to be conducted in post-colonial Africa with regard to the city-urban relationship. Moreover, Africa has numerous post-colonial literary works most of which are based on the urban setting.

This study recommends among other areas, more comparative studies of East African post-colonial urban fiction and the post-colonial urban fiction from West Africa. Another area worth undertaking a study on is Urban Fiction in South Africa in the post-colonial era. The study also recommends for further study a comparative study involving post-colonial urban fiction of former British colonies and that of former French colonies. Lastly, this study recommends a Comparison of Tanzanian Urban Fiction and Kenyan Urban Fiction with a view to establishing any existing distinct features of the two.

\section{REFFERENCE}

1. Kehinde, Ayobami. Aesthetics of Realism: The Image of Postcolonial Africa in Meja Mwangi's going Down River Road". Obafemi Awolowo University, Nigeria: 2004. Jan 2012. Web. 20 May 2016. $<$ ijsse.com/sites/default/files/issues.2012 ..>

2. Kehinde, Ayo. Post-independence disillusionment in Contemporary African Fiction: The Example of Major Mwangi's Kill me Quick; Nordic Journal of African Studies. 13.2 (2004): 228-241. Web. 20 Dec. $\quad 2015 \quad$.<www.njas.helsinki.fi.pdffiles/vol13num2kehinde4.pdf $>$

3. Grossman, Gene $\mathrm{M}$ and Helpman Elhanan. Globalization and Growth. American Economic Review: Papers and Proceedings 105(215) 100104. Web. 20 Feb 2017. < https://scholar.harvard.edu/files/helpman/files/glob alization_growth_aer.p20151068.pdf>

4. Mwangi, Major. Kill Me Quick. Nairobi: EAEP. 1974.

5. Mtobwa, Ben. Give me Money. London: Macmillan; 1988.

6. Mwangi, Major. Going Down River Road. Nairobi: EAEP. 1976.

7. Mtobwa, Ben. Dar es-Salaam by Night. Nairobi: EAEP. 1999.

8. McKeown, Paul Daniel. The Image of the City and Urban Literature: A comparative Study between James Joyce's Dubliners, Hanif Kureishi's The Buddha of Suburbia and Irvine Welsh's Glue; McMaster University, 2004. Web. 20 Feb 2016. <https: //macsphere.mcmaster. ca/bitstream/11375/12122/fultext.pdf>

9. Thiong'o, Ngugi wa. Decolonizing the Mind: Politics of Language in African Literature. Nairobi: EAEP. 1986. Web. 5 Jan 2016.

10. Quigley SP, Youngs JP. Interpreting for Deaf People, a Report of a Workshop on Interpreting (Governor Baxter State School for the Deaf, Portland, Maine, July 7-27, 1965).

11. Hrituleac, Alexandria. The Effects of Colonialism on African Economic Development. A Comparative Analysis between Ethiopia, Senegal and Uganda. Aarhus: Aarhus University, 2011. Web. 10 May 2016.<www.twirpx/com/file/2142133/>

11.12. Ngowi, Honest Prosper. Economic development and change in Tanzania since independence: The political leadership factor. African Journal of Political Science and International Relations 3.2 (2009). Web. 27 Nov 2016. < http: //www.academicjournals.org/AJPSIR> 
12.13. Mtobwa, Ben. Dar es-Salaam Usiku. Dar esSalaam: EAEP; 1986.

13.14. Mtobwa, Ben. Pesa Zako Zinanuka.Dar esSalaam: Heko Publishers, 1984. Print.

14.15. Simmel, Georg. The Metropolis and Mental Life. Bridge, Gary and Watson, Sophie.,Eds. The Blackwell City Reader. Oxford: Willey-Blackwell; 2002. Web. 7 Mar 2017.< https: www. Blackwellpublishing.com/content/BPL_image/cont ent_store/sample_chapter/061225137/Bridge.pdf>

15.16. Robson, James Stephen. Ngugi wa Thiong'o's fight against Colonialism and Neo-colonialism: An exploration of the theme of Betrayal. Burnaby: Simon Frazer University, 1972. Web. 1 Jan 2017.<summit.sfu.ca/systems/files/iritems1/5170/b 14966918.pdf >

16.17. Gromov, Michael D. Swahili Popular Literature in Recent Years. Swahili Forum 15(2008) 5-13. Web. 8 May 2016. $<$ www.qucosa.de/fileadmin/data/qucosa/documents 19098/15_02_Gromov.pdf>

17.18. Musangi, Jennifer Beatrice. A Walk through the Criminal's City: John Kiriamiti's My Life in Crime and My Life in Prison. Johannesburg: University of Watersand, 2008. Web. 30 Sept 2016. <wiredspace.wits.ac.za/bitstream/handle/1053 9/5597/musangi,\%20J\%20B.pdf>

18.19. Alao, Abiodun. Mugabe and the Politics of Security in Zimbabwe. Montreal: McGill- Queen's University Press; 2012. Web. 12 Mar 2017. <http: //www.jstor. org/stable/j.ctt1pq18v>

19.20. Etyang, Philip. Misogyny in Urban Fiction: A study of selected texts by Major Mwangi; Kenyatta University, Kenya, Sept. 2014. Web. 25 Feb 2016. $<$ ir-

library.ku.ac.ke/Misogyny\%20in\%20urban\%20ficti on $\% 20 \mathrm{a} \% 20$ study $\% 20$ of $\% 20 \ldots>$

20.21. Macheka, Mavis Thokozile. An evaluation of post-colonial African leadership" A Study of Ayi Kwei Armah's The Beautiful Ones Are NotYet Born and Chinua Achebe's A Man of the People. International Journal of English and Literature. 5.1(2012). Web. 28 Dec 2016. <http: //
www.academicjournals.org/journalIJEL/articlefultext-pdf/1F7704c42713>

21.22. Wanjala, Chris. For Home and Freedom. Nairobi: Kenya Literature Bureau; 1980.

22.23. Zackheim, Sarah Parsons., and Zackheim, Adrian. Exploring the different types of Fiction....... $<$ https:/www.dummies.com/education /language.arts/creative_writing/exploring_the_diffe rent_types_of_fiction>

23.24. Gerring, John. Ideology: A Definitional Analysis._Boston: Boston University; 1997. Web. $19 \quad$ Mar 2016. <https://psi.ecupl.edu.cn/cp/uploadfiles/ideology\% 20A\%20Definitional\%20Analysis.pdf>

24.25. Fiske, John. Understanding Popular Culture; London: Unwin Hyman; 1989. Web. 15 Dec 2015.<Mountrail.co/understanding_popular_cultur e_john_fiske.pdf $>$

25.26. Lindemann, Stephan.,and James Putzel. Drivers of Change in the Democratic Republic of Congo: The Rise and Decline of the State and Challenges for Reconstruction.London: Crisis States Research Center; 2008. Web. 15 May 2016.

26.27. Lugalla, Joe L.P., and Mbwambo, Jesica Kazeni., Street Children and Street Life in urban Tanzania: The Culture of Surviving and its Implications for Chidren's Health. Dar es-salaam: N; 1996. Web. 17 Dec 2016. < https: //pdfs.semanticscholar.org/c1da/ab56540278f8814f 09do2645ab37e0015.pdf>

27.28. Sommers, Marc. Africa's Young UrbanitesChallenging Realities in a Changing Region. Medford: Tufts University; 2009. Web. 14 Mar $2017 . \quad<$ https: www.unicef.org/ADAP_learning_series_s_Africas _young_urbanites.pdf>

28.29. Mizutani, Shatoshi. Hybridity and History: A Critical Reflection on Homi K. Bhabba's Post Historical Thought. Kyoto: Kyoto University; 2008. Web. 2 Feb 2016.< https: //dx.doi.org/10.14989/134691>

29.30. Mtobwa Ben. Mtambo wa Mauti. Dar esSalaam: Heko Publishers; 2004. 